\title{
Exonucleolytic processing of small nucleolar RNAs from pre-mRNA introns
}

\author{
Tamás Kiss ${ }^{1}$ and Witold Filipowicz \\ Friedrich Miescher-Institut, 4002 Basel, Switzerland
}

\begin{abstract}
Many small nucleolar RNAs (snoRNAs) in vertebrates are encoded within introns of protein genes. We have reported previously that two isoforms of human U17 snoRNA are encoded in introns of the cell-cycle regulatory gene, RCC1. We have now investigated the mechanism of processing of U17 RNAs and of another intron-encoded snoRNA, U19. Experiments in which the processing of intronic RNA substrates was tested in HeLa cell extracts suggest that exonucleases rather than endonucleases are involved in the excision of U17 and U19 RNAs: (1) Cutoff products that would be expected from endonucleolytic cleavages were not detected; (2) capping or circularization of substrates inhibited formation of snoRNAs; and (3) U17 RNA was faithfully processed from a substrate carrying unrelated flanking sequences. To study in vivo processing, the coding regions of snoRNAs were inserted into intron 2 of the human $\beta$-globin gene. Expression of resulting pre-mRNAs in simian COS cells resulted in formation of correctly processed snoRNAs and of the spliced globin mRNA, demonstrating that snoRNAs can be excised from a nonhost intron and that their sequences contain all the signals essential for accurate processing. When the U17 sequence was placed in a $\beta$-globin exon, no formation of U17 RNA took place, and when two U17 RNA-coding regions were placed in a single intron, doublet U17 RNA molecules accumulated. The results support a model according to which $5^{\prime} \rightarrow 3^{\prime}$ and $3^{\prime} \rightarrow 5^{\prime}$ exonucleases are involved in maturation of U17 and U19 RNAs and that excised and debranched introns are the substrates of the processing reaction.
\end{abstract}

[Key Words: Gene expression; small nucleolar RNAs; intron-encoded RNAs; RNA processing; pre-mRNA splicing; exonucleases; introns]

Received December 9, 1994; revised version accepted April 20, 1995.

The nucleoli of eukaryotic cells contain a large number of small nucleolar RNAs (snoRNAs; for review, see Filipowicz and Kiss 1993; Fournier and Maxwell 1993; Sollner-Webb et al. 1995; Maxwell and Fournier 1995). Some of the snoRNAs, such as the U3 in mouse, Xenopus, and yeast (Kass et al. 1990; Savino and Gerbi 1990; Hughes and Ares 1991; Beltrame and Tollervey 1992), U14, snR10, snR30, and 7-2/MRP in yeast (Tollervey 1987; Li et al. 1990; Morissey and Tollervey 1993; Schmitt and Clayton 1993; Chu et al. 1994; Lygerou et al. 1994), and U8 and U22 in Xenopus (Peculis and Steitz 1993; Tycowski et al. 1994) have been demonstrated to be required for the processing of pre-ribosomal RNA (prerRNA). Because other snoRNAs have been found to be associated with pre-rRNAs or with higher order ribonucleoprotein complexes, likely to represent ribosomal precursors, they may all be involved in aspects of ribosome biogenesis or transport (for review, see Fournier and Maxwell 1993; Sollner-Webb et al. 1995; Maxwell and Fournier 1995).

The snoRNAs form part of small ribonucleoprotein particles (snRNPs), and most are precipitable with antibodies against fibrillarin, an evolutionarily conserved

'Present address: Laboratoire de Biologie Moléculaire Eucaryote du CNRS, Université Paul-Sabatier, 31062 Toulouse CEDEX, France. nucleolar protein (Fournier and Maxwell 1993; SollnerWebb et al. 1995). The fibrillarin-associated snoRNAs share a common stem-loop-stem structural motif comprising two conserved sequence elements, designated box $C$ (or $C^{\prime}$ ) and box D (Tycowski et al. 1993; and refs. therein). SnoRNAs that are not precipitable with antifibrillarin antibodies include 7-2/MRP RNA and four recently characterized RNAs: U17/E1 (Kiss and Filipowicz 1993; Ruff et al. 1993; Cecconi et al. 1994), E2 and E3 (Ruff et al. 1993), and U19 (T. Kiss and W. Filipowicz, (in prep.). 7-2/MRP RNA is associated with the Th/To antigen (Hashimoto and Steitz 1983; Reddy et al. 1983), but proteins associated with the other RNAs have not been identified.

In vertebrates, the most abundant snoRNAs are synthesized from independent transcription units by RNA polymerase II (Pol II) or Pol III and have promoter elements identical to those described for spliceosomal $U$ small nuclear RNA (snRNA) genes. The U3, U8, and U13 RNAs, which are Pol II products, acquire a trimethylguanosine $\left(\mathrm{m}_{3} \mathrm{G}\right)$ cap characteristic of all Pol II-synthesized U snRNAs, whereas the Pol III-transcribed 7-2/MRP RNA contains a pppN $5^{\prime}$ end (for review, see Hernandez 1992). In contrast to U3, U8, U13, and 7-2/MRP RNAs, most of the other known snoRNAs (U14-U22) are not transcribed from independent genes but are encoded within introns of genes coding for proteins (Liu and Max- 
well 1990; Leverette et al. 1992; Fragapane et al. 1993; Kiss and Filipowicz 1993; Prislei et al. 1993; Tycowski et al. 1993; Cecconi et al. 1994; Nicoloso et al. 1994; Qu et al. 1994; Tycowski et al. 1994). Because these snoRNAs are processed from pre-mRNA transcripts, their 5' ends are not capped but, rather, contain a monophosphate group (Kiss and Filipowicz 1993; Nag et al. 1993; Tycowski et al. 1993).

Many of the genes that act as hosts for intronic snoRNAs code for proteins essential for ribosome biogenesis or function. For example, snoRNAs U15, U16 and $U 18$, and $U 21$ are found in the genes for ribosomal proteins, S3, L1, and L5, respectively (Fragapane et al. 1993; Prislei et al. 1993; Tycowski et al. 1993; Qu et al. 1994), whereas U20 RNA is cotranscribed with premRNA for the nucleolar protein nucleolin (Nicoloso et al. 1994). Among the few exceptions to this rule are U14 RNA, which is located in a cognate $h s c 70$ heat shock gene (Liu and Maxwell 1990; Leverette et al. 1992), and human U17 RNA, which is present in the gene encoding the chromatin-associated cell-cycle regulatory protein RCCl (Kiss and Filipowicz 1993). It has been suggested that cotranscription of snoRNAs with mRNAs for ribosomal or nucleolar proteins may provide a regulatory mechanism to coordinate accumulation of different components and factors required for ribosome biogenesis (Fragapane et al. 1993; Prislei et al. 1993; Tycowski et al. 1993; Nicoloso et al. 1994). Similarly, coexpression of U17 RNA with pre-mRNA encoding a mitotic regulator, $\mathrm{RCCl}$, may provide a subtle mechanism for coupling ribosome biogenesis with the cell cycle (Kiss and Filipowicz 1993).

To understand how expression of intron-encoded snoRNAs and their host mRNAs is coordinated it is important to determine the mechanism of snoRNA processing. Such an understanding may also provide insight into the evolution of hybrid mRNA/snoRNA genes. The processing of the fibrillarin-associated U16 RNA, which is encoded in the third intron of the Xenopus ribosomal protein $\mathrm{L} 1$ gene, has been studied most extensively to date. Bozzoni and co-workers (Fragapane et al. 1993; Prislei et al. 1993; Caffarelli et al. 1994) have found that pre-mRNA fragments containing the $L 1$ gene intron 3 are either spliced, leading to the production of mature mRNA, or are cleaved endonucleolytically within the intron. The latter process results in the release of U16 RNA precursors from which the $5^{\prime}$ and $3^{\prime}$ trailer sequences are subsequently removed. The results of these experiments suggest that pre-mRNA molecules, and not excised introns, serve as substrates for U16 RNA processing, indicating that pre-mRNA splicing and snoRNA formation are mutually exclusive reactions. A similar pathway of excision has been proposed for U18 RNA, which is encoded in other introns of the $L 1$ gene (Prislei et al. 1993).

Faithful processing from intronic RNA substrates, either in microinjected Xenopus oocytes or in vitro, has also been demonstrated for other snoRNAs, including U14 (Leverette et al. 1992), U15 (Tycowski et al. 1993), U17 (Kiss and Filipowicz 1993), and U20 (Nicoloso et al.
1994). For U15 and U17 RNAs, in vitro processing appears to follow a similar pattern: First, these snoRNAs are either fully processed at their $5^{\prime}$ ends or partially processed at 3 ' ends, indicating that the formation of the two ends may occur independently (Kiss and Filipowicz 1993; Tycowski et al. 1993). The resulting intermediates, having 5- to 8-nucleotide-long 3'-terminal trailers, are finally processed into mature snoRNAs (Kiss and Filipowicz 1993).

In this work we have investigated the mechanism of the processing of U17 and U19 RNAs, two snoRNAs that are not associated with fibrillarin. In vitro experiments, performed with HeLa cell extracts, provide evidence that these RNAs are processed by exonucleolytic activities and that their coding regions contain all the signals required for faithful excision. These conclusions are supported by results of in vivo experiments in which excision of snoRNAs from the host and nonhost introns was studied in transfected COS cells. The results support a model according to which $5^{\prime} \rightarrow 3^{\prime}$ and $3^{\prime} \rightarrow 5^{\prime}$ exonucleases are involved in maturation of U17 and U19 RNAs and excised and debranched introns are the most likely substrates in the processing reaction.

\section{Results}

Exonucleolytic activities are responsible for the in vitro processing of the $5^{\prime}$ and $3^{\prime}$ termini of U17 snoRNAs

Two isoforms of the human U17 snoRNA, U17a and $\mathrm{U} 17 \mathrm{~b}$, are encoded in introns 1 and 2 of the $R C C 1$ gene, respectively. We have reported previously that fragments of the RCC1 gene transcripts containing the U17a RNAcoding region flanked by its natural intron sequences are processed into mature U17a RNA when incubated in HeLa extract (Kiss and Filipowicz 1993). The in vitro processing was shown to be precise at the $5^{\prime}$ end and most probably also at the $3^{\prime}$ end of U17 RNA. The $5^{\prime}$ - and $3^{\prime}$-terminal cutoff fragments were not detected, suggesting that processing at both ends may be catalyzed by exonucleases.

We have now tested more directly whether exonucleolytic or endonucleolytic activities are responsible for maturation of U17 RNA. To investigate 5 ' end processing, we used ${ }^{32} \mathrm{P}$-labeled T7 RNA polymerase transcripts comprising U17a RNA-coding region flanked by the upstream and downstream sequences from intron 1 of the RCC1 gene (see Fig. 1; Kiss and Filipowicz 1993) and containing either uncapped (pppN) or capped $\left(\mathrm{m}^{7} \mathrm{GpppN}\right)$ $5^{\prime}$ terminus. Capping of the RNA would be expected to block its degradation by the $5^{\prime} \rightarrow 3^{\prime}$ processing exonuclease (Murthy et al. 1991; Muhlrad et al. 1994). Incubation of the uncapped substrate with HeLa extract resulted in a time-dependent accumulation of apparent processing intermediates and of a product the size of mature U17a RNA (Fig. 1, left). Three of the processing products have been characterized previously by RNase $\mathrm{A} / \mathrm{T}_{1}$ mapping and analysis of the 5 '-terminal nucleotides. Product a 3 ' corresponds to RNA partially pro- 

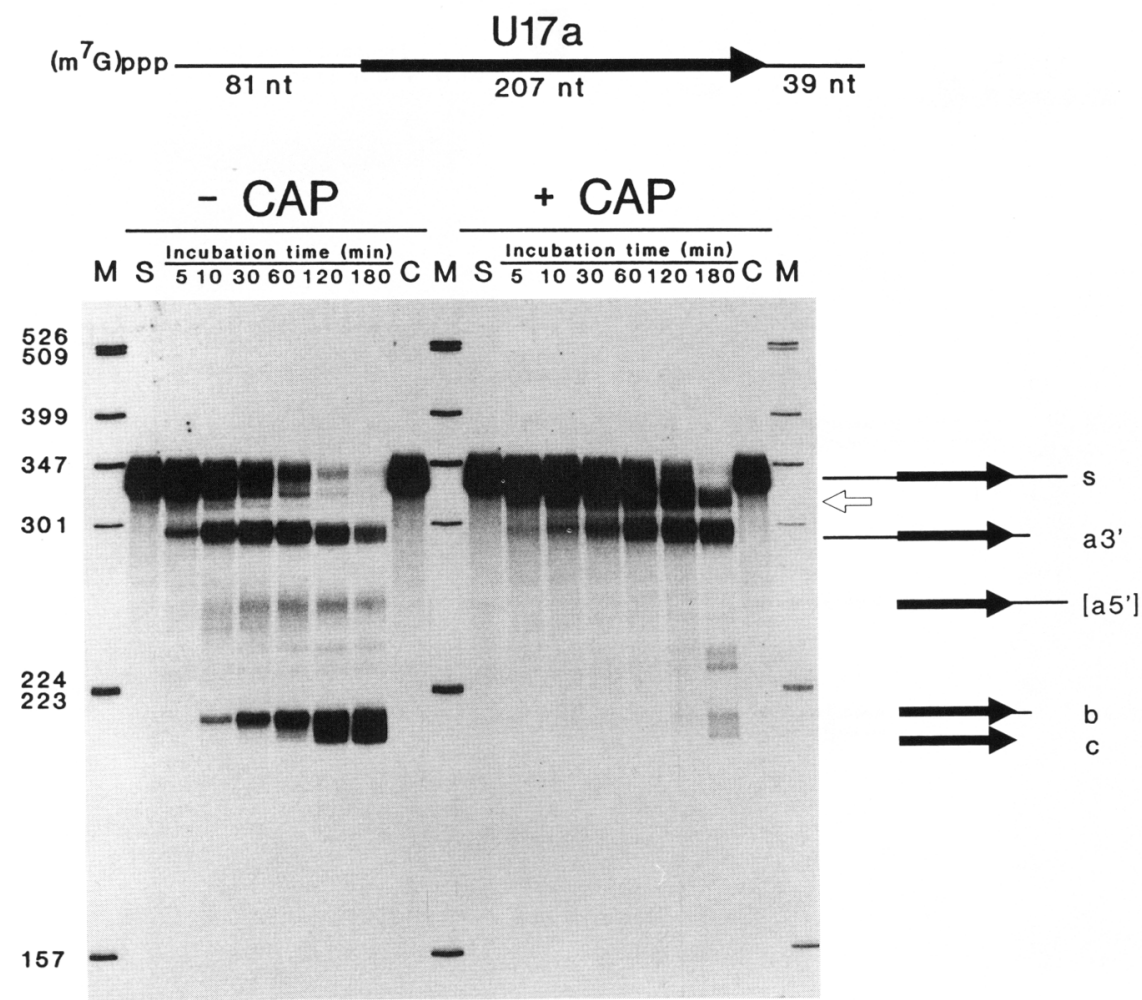

Figure 1. Time course analysis of the in vitro processing of U17a snoRNA from noncapped (-CAP) and $\mathrm{m}^{7}$ Gcapped $(+\mathrm{CAP})$ intronic transcripts. Internally ${ }^{32}$ P-labeled substrate RNAs, schematically represented at the top, were incubated in a HeLa extract and aliquots were taken at the time points indicated. RNA products were separated on a $6 \%$ sequencing gel. (Lanes $\mathrm{S}$ and C) RNA substrates incubated in the absence of cell extract for 0 and $3 \mathrm{hr}$, respectively. (Lanes $M$ ) Size markers (Hinfl-digested pBR322). Processing products, characterized previously by RNase $A / T_{1}$ mapping (Kiss and Filipowicz 1993), are schematically represented at right. The product a5', shown in brackets, was not characterized by RNase mapping; its identity is inferred from its size and the effect of capping on its accumulation (see also Results; Fig. 2A). It should be noted that final $3^{\prime}$ end maturation of U17 RNA /and U19 RNA; see below) may take place also on the a3' RNA. Although the kinetics of the appearance of most of the products suggests that partially processed RNAs represent processing intermediates, this has not been directly demonstrated. The RNA marked with an open arrow represents a substrate RNA shortened at the $3^{\prime}$ end. Similar time-dependent shortening is also seen with U19 substrates (see Fig. 4A) and RNAs devoid of snoRNA-coding regions (not shown). This modification is probably unrelated to snoRNA processing. cessed at the $3^{\prime}$ end but still containing the 5- to 8-nucleotide-long $3^{\prime}$-trailer (for additional details, see the legend to Fig. 1). Product b has the same $3^{\prime}$ end as a $3^{\prime}$ but, in addition, has been correctly processed at the $5^{\prime}$ end. Product $\mathrm{c}$ represents mature U17a snoRNA that has been processed at both ends (Kiss and Filipowicz 1993). Product a5', which was not characterized before, most likely corresponds to RNA processed at the $5^{\prime}$ but not at the $3^{\prime}$ end, as inferred from its size and the effect of capping on its accumulation (see below). The time course of the processing of the capped substrate is shown in Figure 1 (right). Capping of the RNA $5^{\prime}$ terminus resulted in an overaccumulation of the $3^{\prime}$ end-processed products $a 3^{\prime}$. In contrast, the levels of RNAs processed at the $5^{\prime}$ end (products $\mathrm{a} 5^{\prime}, \mathrm{b}$, and c) were markedly reduced.

We next investigated the in vitro excision of the U17b RNA from intron 2 of the $R C C 1$ gene. Because this intron is considerably shorter than intron 1 (669 vs. 2029 nucleotides), it was possible to prepare in vitro transcripts that encompass the entire intron sequence. The analysis of the processing of the U17b RNA substrates, both uncapped and capped, is shown in Figure 2A. The $\mathrm{U} 17 \mathrm{~b}$ processing products were similar to those observed for the U17a substrates (cf. Figs. 1 and 2A), except in the case of the U17b substrates, the $\mathrm{a} 5$ ' product, corresponding to RNA processed at the $5^{\prime}$ end but not at the $3^{\prime}$ end, was present in significantly higher amounts (for details of the characterization of this and other products, see the legend to Fig. 2A|. Capping of the U17b substrate re- sulted in a decreased formation of products $a 5^{\prime}, \mathrm{b}$, and c, and in accumulation of the product $\mathrm{a} 3^{\prime}$, which is unprocessed at the $5^{\prime}$ end. The findings that capping of the $\mathrm{U} 17 \mathrm{a}$ and U17b substrates specifically interferes with 5 '-end processing and that fragments corresponding in size to the cutoff intron sequences are not detected among the processing products suggest that a $5^{\prime} \rightarrow 3^{\prime}$ exonuclease activity is responsible for the $5^{\prime}$-end formation of U17 RNAs.

Processing of the $3^{\prime}$ terminus of U17a and U17b RNAs appears to occur in two distinguishable steps. In the first, most of the downstream flanking sequence is removed, resulting in accumulation of intermediates containing 5to 8-nucleotide-long 3'-terminal trailers (products a3' and $\mathrm{b}$ ). In the second step, the trailers are removed slowly, most probably by an exonucleolytic activity, resulting in formation of mature $3^{\prime}$ ends (Kiss and Filipowicz 1993; see also Figs. 1 and 2A). To test whether endo- or exonucleases are responsible for generation of the $3^{\prime}$ end-extended $\mathrm{a} 3^{\prime}$ or b products, the U17a and $\mathrm{U} 17 \mathrm{~b}$ processing substrates described in Figures 1 and $2 \mathrm{~A}$ were circularized covalently by T4 RNA ligase and incubated with the HeLa extract. If exonucleases are involved, the absence of free $5^{\prime}$ and $3^{\prime}$ termini should inhibit formation of U17 RNAs. It was found that circular RNA substrates carrying either U17a (data not shown) or $\mathrm{U} 17 \mathrm{~b}$ (Fig. 2B) sequences were very resistant to nucleases, with no processing or degradation observed even after $3 \mathrm{hr}$ of incubation with the extract (for possible 
A
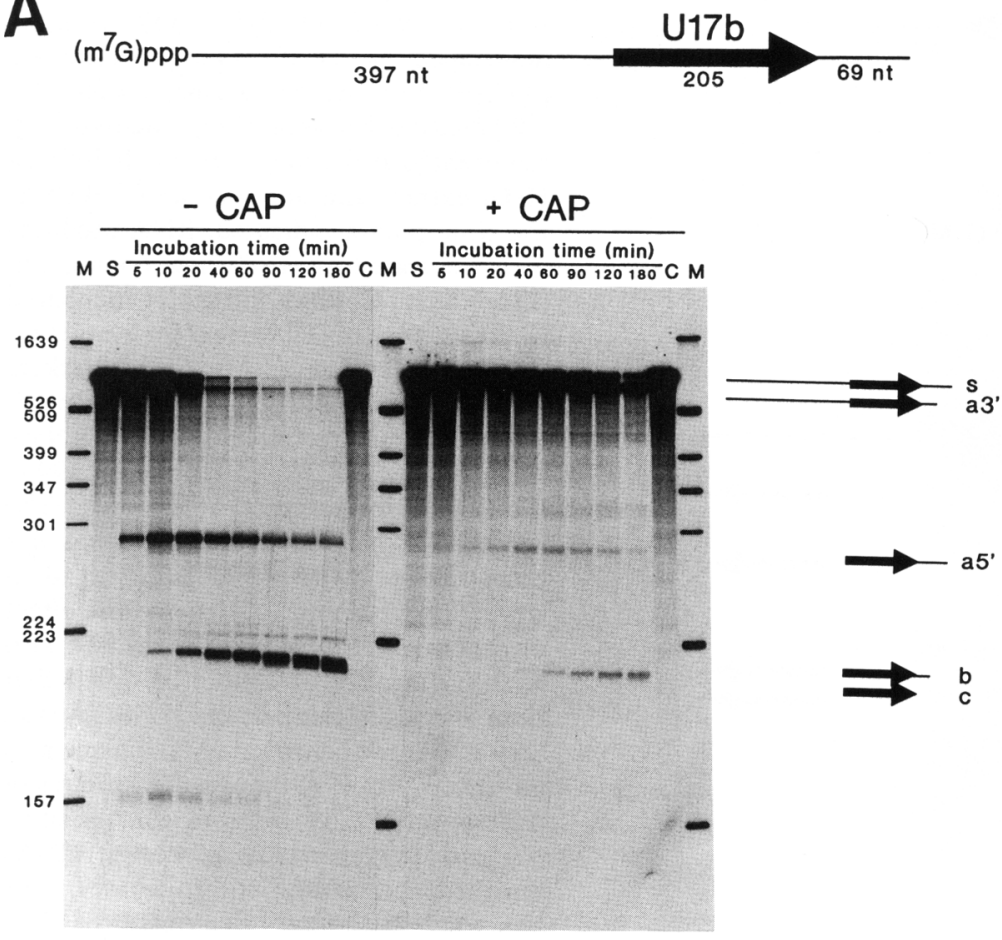

B

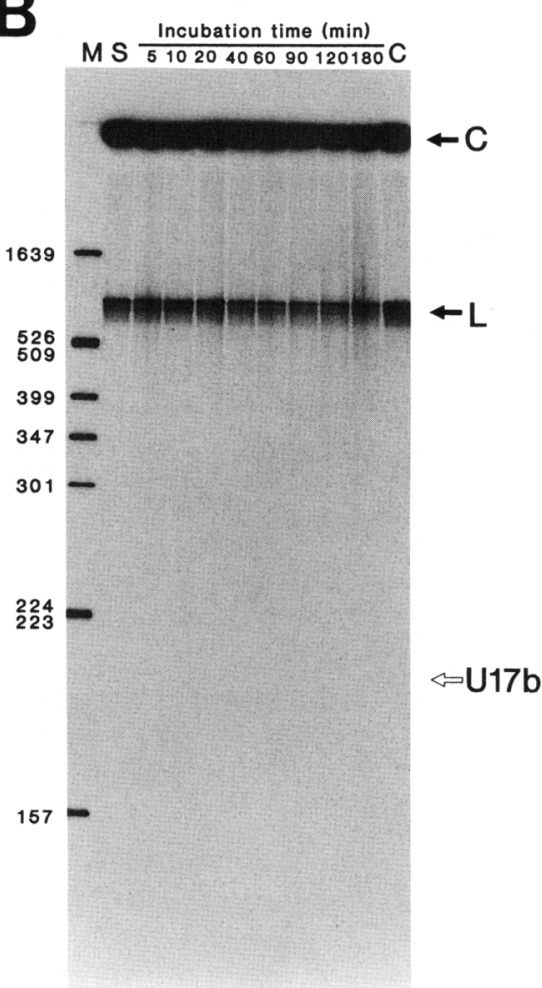

Figure 2. In vitro processing of U17b RNA. $|A|$ Time-dependent processing of U17b RNA from noncapped $(-$ CAP) and capped (+CAP) substrate RNA. The U17b/T7 substrate RNA, schematically shown at the top, spans the entire intron 2 of the RCC1 gene and contains at the $5^{\prime}$ end two additional $\mathrm{G}$ residues originating from the $\mathrm{T} 7$ promoter. The identity of processing products, shown at the right, was verified by RNase mapping with probes complementary to the $5^{\prime}$-flanking region and the 5 '-terminal portion of U17b RNA. $(B)$ In vitro processing of the circular U17b/T7 RNA substrate. The internally labeled U17b/T7 RNA was circularized by T4 RNA ligase and incubated with the HeLa cell extract. Positions of the circular $(\mathrm{C})$ and the linear $(\mathrm{L})$ forms of the substrate RNA and the expected position of mature U17b RNA are indicated at right. (Lanes S and C) RNA substrate incubated in the absence of the HeLa extract for 0 and $3 \mathrm{hr}$, respectively. (For other details, see the legend to Fig. 1.) We investigated whether the reason why linear RNA molecules, which result from a single-hit hydrolytic cleavage of circles during purification, are not processed is attributable to the nature of their termini: $5^{\prime}-\mathrm{OH}$ and a phosphate at the $3^{\prime}$ terminus. U17a processing substrates bearing either pppN and $3^{\prime}-\mathrm{OH}, \mathrm{pN}$ and $3^{\prime}-\mathrm{OH}$, or $5^{\prime}-\mathrm{OH}$ and $3^{\prime}-\mathrm{p}$ ends (the latter obtained by subjecting phosphatase-treated RNA to $\beta$-elimination) were assayed in the HeLa extract, but no significant differences in their processing were apparent. The lack of processing may alternatively be attributable to the presence of a cyclic phosphate at the 3' end or ineffective packaging of the RNA into RNP because of the hydrolysis occurring in the U17-coding region. Notably, RNAs devoid of snoRNA sequences are considerably more stable in HeLa extract than the genuine U17 RNA processing substrates (T. Kiss and W. Filipowicz unpubl.).

reasons as to why linear RNA molecules, which result from single hit hydrolytic cleavage of circles during purification, do not yield processed U17 RNA, see the legend to Fig. 2B).

\section{Elements essential for processing of U17 RNA are contained within its coding region}

Inspection of sequences flanking the $\mathrm{U} 17 \mathrm{a}$ and $\mathrm{U} 17 \mathrm{~b}$ RNA-coding regions did not reveal any obvious sequence or secondary structure elements conserved between the two introns. To test the importance of flanking sequences for processing of U17 RNA in vitro, we prepared an RNA substrate in which the U17a RNA-coding region is flanked, both downstream and upstream, by the sequences originating from the pBluescribe polylinker (Fig.
3). Incubation of this RNA with the HeLa extract resulted in a time-dependent accumulation of processing products similar to those seen with the U17a substrate containing authentic flanking sequences /cf. Figs. 3 and 1). The faithful in vitro processing of U17a from the artificial substrate is consistent with exonucleases being responsible for processing of the U17 RNA (see Discussion). This experiment also demonstrates that elements essential for U17a excision are located within the U17 RNA-coding region.

\section{Exonucleases are also involved in the processing of U19 RNA in vitro}

We have recently characterized a novel 200 -nucleotidelong human snoRNA, called U19, which is encoded in 

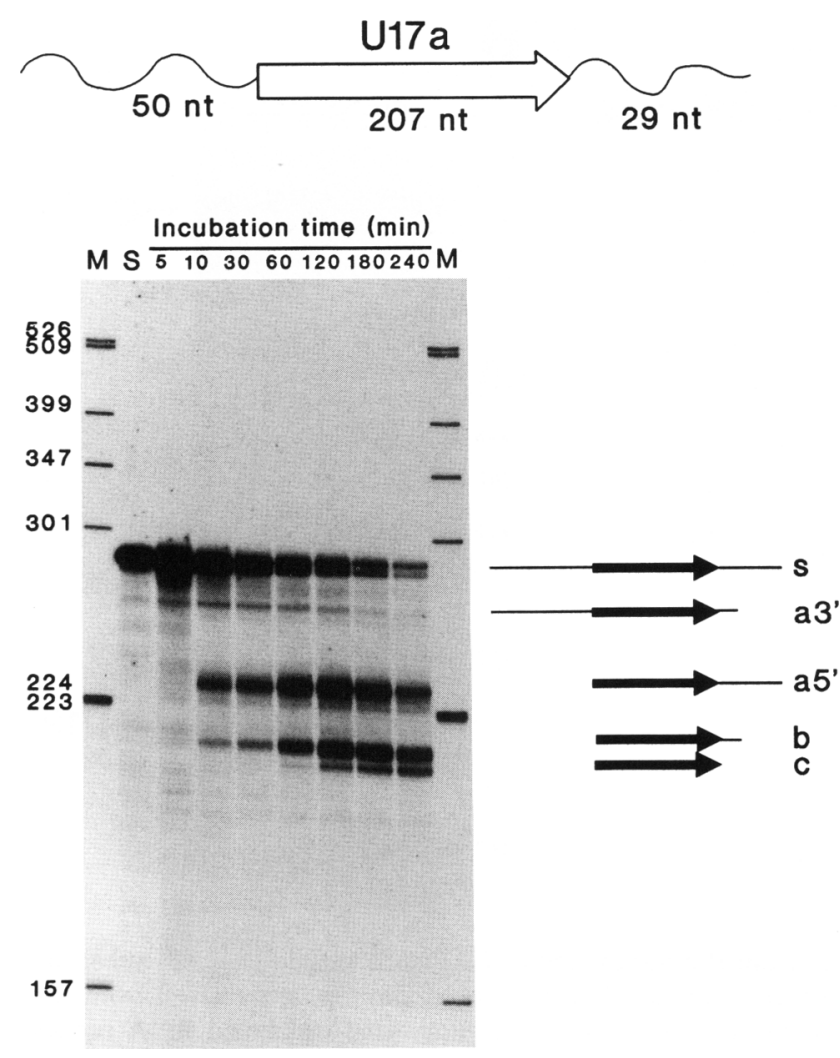

Figure 3. In vitro processing of U17a RNA from a substrate containing altered flanking sequences. The structure of the substrate RNA is shown at the top. Wavy lines indicate sequences originating from the pBluescribe polylinker. Two residues adjacent to the 3' end of the U17a RNA correspond to the authentic intron-encoded nucleotides. (Lane S) Nonincubated substrate. Processing products are indicated at right. (For other details, see the legend to Fig. 1.)

the intron of a gene not fully characterized as yet (Filipowicz and Kiss 1993; T. Kiss and W. Filipowicz, in prep.). The U19 RNA is conserved among different mammals and belongs to the family of snoRNAs that are not precipitable with the anti-fibrillarin antibodies. It can be processed from longer RNA precursors in vitro, yielding mature U19 RNA-sized product bearing the 5'-phosphate and $3^{\prime}-\mathrm{OH}$ termini. To investigate whether processing of U19 RNA in vitro occurs by a mechanism similar to that established for U17 RNAs, we have tested the effects of capping and circularization on its excision. Consistent with the involvement of a $5^{\prime} \rightarrow 3^{\prime}$ exonuclease in U19 processing, blocking of the $5^{\prime}$ terminus of the substrate RNA with an $\mathrm{m}^{7} \mathrm{G}$ cap resulted in accumulation of products $\mathrm{a} 3^{\prime *}$ and $\mathrm{a} 3^{\prime}$, which are partially processed at the $3^{\prime}$ end but contain unaltered $5^{\prime}$ ends. In addition, formation of the $5^{\prime}$ end-processed products $b$ and $\mathrm{c}$ was almost abolished (Fig. 4A; see legend for more detailed description of the processing products). Incubation of the circularized U19 substrate RNA with the HeLa extract did not result in accumulation of any processing products (Fig. 4B), demonstrating that exonu- cleases are probably involved in processing at both ends of the U19 RNA in vitro. The product a3'*, which accumulates when the $5^{\prime}$ terminus of the processing substrate is capped, contains a sequence at its $3^{\prime}$ end with a potential to form an 11-bp hairpin (see Fig. 4). Therefore, product $\mathrm{a} 3^{\prime *}$ may accumulate as a result of pausing of an exonuclease at this structure. However, it is also possible that this RNA is a dead-end product.

\section{U17 RNA is processed out of a short RCCl gene fragment expressed in COS cells}

The results presented above demonstrate that exonucleases rather than endonucleases are involved in the processing of both the $5^{\prime}$ and $3^{\prime}$ ends of U17 and U19 RNAs in vitro. Moreover, experiments with the capped and circular U17b substrates, encompassing the entire $R C C 1$ intron 2 indicate that if endonucleolytic cleavages of the pre-mRNA are responsible for generating free 5' and $3^{\prime}$ termini / which then act as entry sites for exonucleases), such cleavages would have to occur outside of the intron sequence. An alternative and more plausible hypothesis is that linear, debranched introns, the products of pre-mRNA splicing, act as substrates for exonucleases. To distinquish between these possibilities, we have investigated the relationship between splicing and processing of U17 and U19 RNAs in vivo, using transfected COS cells.

A short fragment of the $R C C 1$ gene, encompassing the entire intron 2 , and 32 and 28 bp of the flanking exons 2 and 3 , respectively, was cloned behind the cytomegalovirus (CMV) promoter in the expression vector $\mathrm{pCB} 6$, and the resulting construct, called $\mathrm{pE}$ (Fig. 5A), was transfected into COS cells. RNA was isolated $48 \mathrm{hr}$ after transfection and subjected to RNase $A / T_{1}$ mapping with ${ }^{32} \mathrm{P}$-labeled RNA probes complementary either to the entire cloned RCC1 fragment (Fig. 5) or to the spliced form of pre-mRNA (data not shown). A protected band corresponding in size to the mature human U17b RNA was detected in transfected COS cells (lane 5) but not in control nontransfected cells (lane 3). Mapping of RNA isolated from transfected cells revealed the presence of correctly spliced exons 1 and 2 (data not shown) and of some unspliced RNA (lane 5). This experiment indicates that human U17 RNA can be distinguished from the endogenous simian U17 RNA by RNase mapping and, more importantly, that it can be faithfully processed in simian cells. The finding that $\mathrm{pE}$ transcripts, containing only short stretches of the RCC1 exons, yield correctly excised U17 RNA makes it rather unlikely that processing involves endonucleolytic cleavages within sequences flanking intron 2 of the gene. In addition, we have tested processing of mutant $\mathrm{pE}$ transcripts with either sequences of the RCC1 exons and the adjacent splice sites deleted or mutations in the $3^{\prime}$ and $5^{\prime}$ splice junctions. In either case, the accumulation of the U17 RNA in transfected COS cells was dramatically reduced (data not shown). However, interpretation of these experiments is difficult because introduced mutations decreased the 

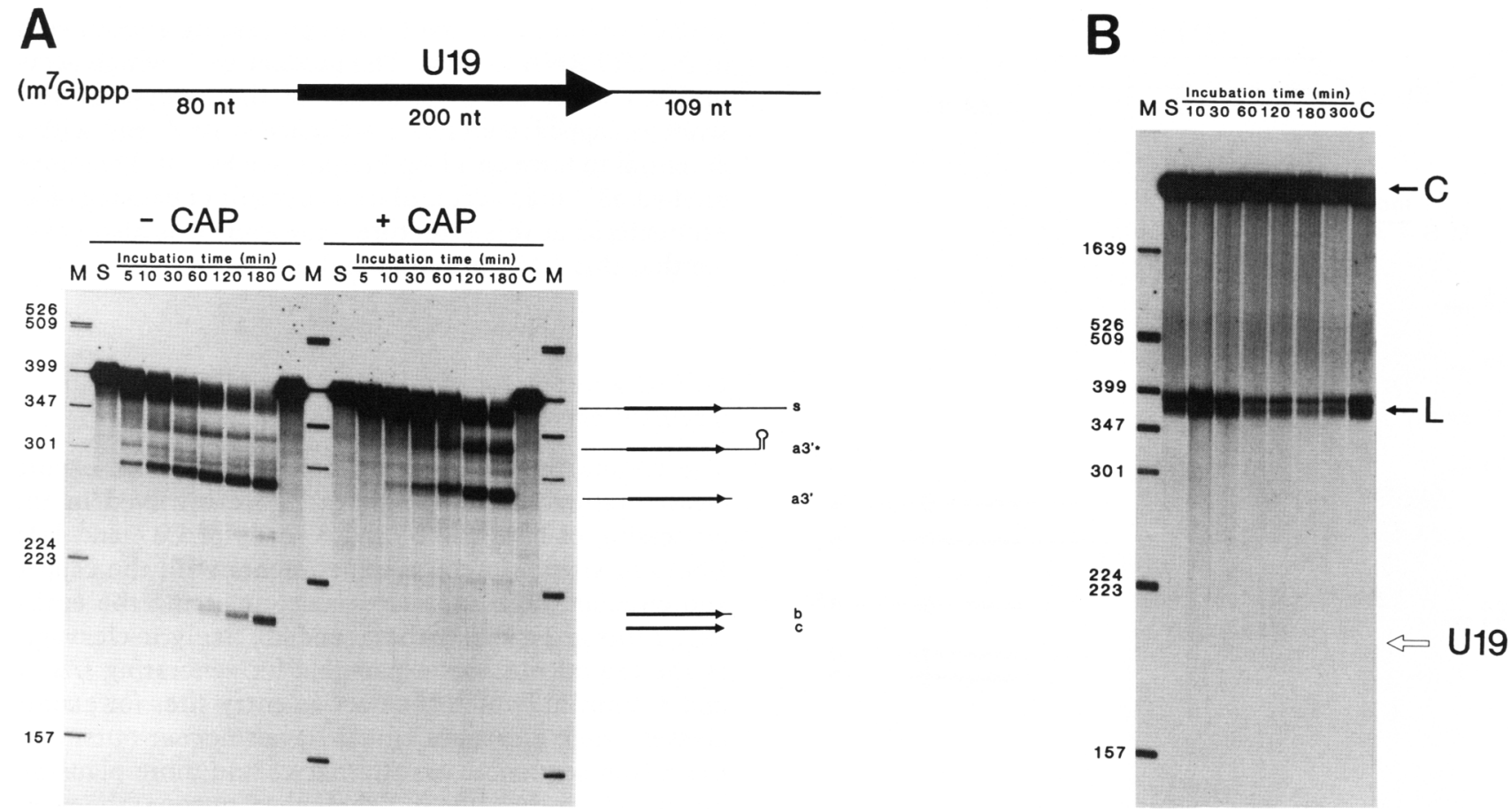

Figure 4. In vitro processing of U19 RNA. (A) Processing of U19 RNA from the noncapped (-CAP) and capped (+ CAP) substrate RNA. The six 5'-terminal and two 3 '-terminal nucleotides of the substrate, shown schematically at the top, are derived from the cloning vector. The structure of the products, shown at right, was determined by RNase mapping with unlabeled RNA probes complementary to the $5^{\prime}$ and $3^{\prime}$ halves of the U19/T7 substrate; product c contains the $5^{\prime}$-monophosphate and $3^{\prime}$-OH termini (T. Kiss and W. Filipowicz, in prep.). The $3^{\prime}$-terminal sequence of product a3'* (positions 21-48, downstream of the $3^{\prime}$ end of U19 RNA) has the potential to form an 11-bp hairpin (GACAGGUUGUCUUAGGGACAGCCUGUC; complementary nucleotides are underlined). It is not known whether the hairpin is formed under the in vivo processing conditions. (For other details, see Fig. 1.) (B) Incubation of the circular U19 RNA substrate with the HeLa cell extract. (For more details, see legend to Fig. 2B.)

steady-state levels of transcribed RNA, probably as a result of the lack of functional introns.

\section{U17 and U19 RNAs are processed from introns of} human $\beta$-globin pre-mRNA expressed in COS cells

The experiments presented thus far are most consistent with a model in which U17 and U19 RNAs are processed from the spliced and linearized introns in vivo. If splicing and debranching are the only prerequisites for processing, the U17 and U19 RNAs should be excised from introns of any actively spliced pre-mRNA. To test this assumption, the coding regions of the U17a, U17b, and U19 RNAs were inserted into the second intron of the human $\beta$-globin gene cloned in the $\mathrm{PCB} 6$ vector, yielding constructs $\mathrm{pA}, \mathrm{pB}$, and $\mathrm{pR}$, respectively. Construct $\mathrm{pG}$ contains the wild-type human $\beta$-globin gene (Fig. 6A,B). Formation of U17 and U19 RNAs, and splicing of the globin introns in transfected COS cells, was assayed by RNase mapping with probes specific for each of the pre-mRNAs (Fig. 6A, lanes 9-21; Fig. 6B); additional control mappings were performed with short probes specific for U17a and U17b RNAs (Fig. 6A, lanes 1-8). All three human snoRNAs were processed from the $\beta$-globin
pre-mRNA intron, yielding RNAs identical in size to the authentic human snoRNAs (Fig. 6A, cf. lanes 2, 4, and 17 and lanes 6,8 , and 21 ; Fig. 6B). Globin pre-mRNAs containing snoRNA inserts were also spliced efficiently and correctly as demonstrated by the presence of exon-specific protected fragments (Fig. 6A, lanes 11-21; Fig. 6B). Comparison of expression of the wild-type globin gene (construct pG) with that of the individual hybrid $\beta$-globin/snoRNA genes revealed that insertions of snoRNA-coding regions had no effect on accumulation of the spliced $\beta$-globin mRNA (Fig. 6A, lanes 11-13, 16, $17,20,21$; Fig. $6 \mathrm{~B}$, lanes 4,5$)$. This is consistent with the notion that the primary pre-mRNA/snoRNA transcripts first undergo splicing and that excised introns are substrates for the processing of these snoRNAs.

We have investigated whether a change in the host gene with which U17 RNAs are coexpressed has any effect on their intracellular localization. COS cells transfected with either $\mathrm{pA}$ or $\mathrm{pB}$ plasmids were fractionated into cytoplasmic, nuclear, nucleoplasmic, and nucleolar fractions, and the distribution of U17a and U17b RNAs measured by RNase mapping (Fig. 6C). Both U17 RNA isoforms processed from the $\beta$-globin pre-mRNA, as well as the endogenous monkey U17 RNA, were found to be highly enriched in the nucleolar fraction. 

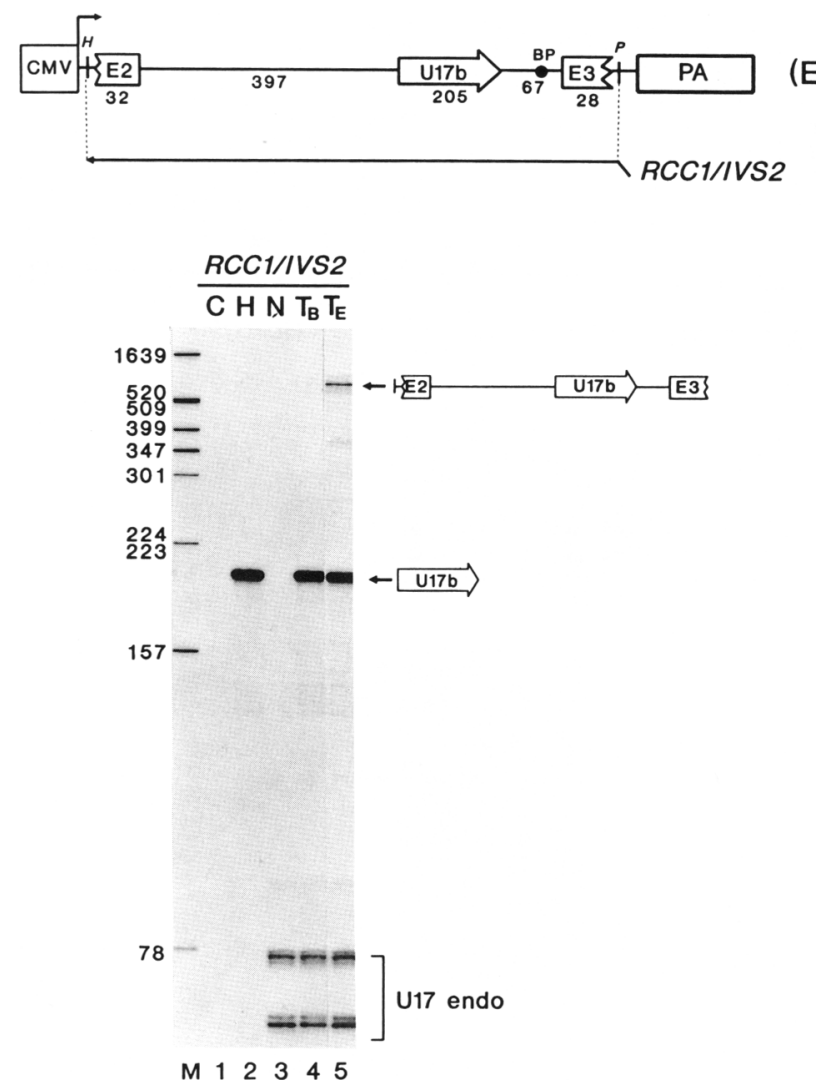

Figure 5. Processing of U17b RNA from the second intron of the $R C C 1$ gene in transfected COS cells. RNase $\mathrm{A} / \mathrm{T}_{1}$ mapping with a pre-mRNA-specific probe. The schematic structure of the $\mathrm{pE}$ construct used for transfection is shown at the top. CMV and PA denote the promoter and the polyadenylation regions of the vector. Positions of the putative branch point $(\mathrm{BP})$ and of the restriction sites used for cloning $(H$, HindIII; $P, P s t \mathrm{I})$ are indicated. The RCCl/IVS2 probe used for mapping is shown below. The following RNA samples were analyzed: (lane C) Escherichia coli tRNA; (lane $\mathrm{H})$ total HeLa cell RNA $(0.5 \mu \mathrm{g})$; (lane N) RNA $(2 \mu \mathrm{g})$ from nontransfected COS cells; (lanes $T_{B}$ and $T_{E}$ ) RNA $(2 \mu \mathrm{g})$ from COS cells transfected with constructs $\mathrm{pB}$ and $\mathrm{pE}$, respectively. The $\mathrm{pB}$ construct used as a control in this experiment is described in Fig. 6. Positions and structures of protected fragments are indicated at right. (U17 endo) Fragments corresponding to the endogenous simian U17 RNA.

U17 RNA is not excised when placed in the exon of the $\beta$-globin gene

To investigate further the notion that excised introns act as physiological substrates for snoRNA processing, we tested whether U17 snoRNA can be excised when placed in the exon of a pre-mRNA. The coding region of U17a RNA was inserted into exon 2 of the human $\beta$-globin gene (see Fig. 7), and the resulting construct was expressed in COS cells. The resulting pre-mRNA was spliced correctly, but no protected fragments corresponding to processed U17a RNA were observed. The size of the spliced exon 2 (445 nucleotides) indicated that the U17a RNA sequence remained part of the spliced mRNA
(Fig. 7, lane 5). The identity of this exon 2-specific fragment was established further by additional RNase $A / T_{1}$ mapping performed with an RNA probe complementary to the $3^{\prime}$ half of U17a RNA and the adjacent exon 2 sequence (data not shown). This experiment demonstrates that U17 RNA cannot be processed from premRNA transcript when it forms part of an exon.

\section{Only a single snoRNA can be processed faithfully from a single intron}

Pre-mRNA transcripts that contain snoRNAs often carry several sequence variants of the same snoRNA (Liu and Maxwell 1990; Fragapane et al. 1993; Kiss and Filipowicz 1993; Tycowski et al. 1993; Cecconi et al. 1994) or, in some cases, two distinct snoRNA species (Prislei et al. 1993; Maxwell and Fournier 1995) located in different introns of the same gene. Interestingly, although a single intron could easily accommodate the coding regions of two or more snoRNA molecules, there is no reported example of this kind. To investigate the significance of the "one intron-one snoRNA" rule, two different snoRNA-coding regions, U17a and U17b, separated by a 36-bp spacer, were inserted into the second intron of the human $\beta$-globin gene, resulting in a construct, $\mathrm{pAB}$ (Fig. $8 \mathrm{~A})$. The pAB transcript was spliced accurately in COS cells (Fig. 8A, lane 5). However, instead of single mature $\mathrm{U} 17 \mathrm{a}$ and U17b RNAs, a fragment corresponding in size to the tandem U17 RNA, which is correctly processed at the $5^{\prime}$ end of U17a and at the $3^{\prime}$ end of U17b sequence, accumulated (lane 5). The identity of this fragment was verified by additional RNase mapping with a probe specific to the U17b and spacer regions (data not shown). It is important to point out that regions adjacent to the U17a $3^{\prime}$ end and to the U17b $5^{\prime}$ end in the spacer between the RNAs in construct pAB contain 4 and $29 \mathrm{nu}-$ cleotides of the authentic RCC1 gene intron sequences, respectively (see Fig. 8A; Materials and methods). Despite that, no cleavage occurred at the $3^{\prime}$ end of U17a or at the $5^{\prime}$ end of U17b, and this argues further against sequence-specific endonucleases being involved in processing at these sites.

We tested whether the insertion of an exon between the tandem U17a and U17b sequences is sufficient to restore correct processing of both U17 RNAs. To this end, the second exon of the adenovirus major late (AdML) transcription unit, flanked by short intronic sequences encompassing its splicing signals, was inserted between the U17a and U17b regions, to yield construct pAD (Fig. 8B). As a control, a fragment of a similar length originating from $R C C 1$ intron 2 was inserted into the same region, resulting in construct $\mathrm{pC}$. When the $\mathrm{pAD}$ construct was expressed in COS cells, the AdML exon was found to be spliced correctly to exons 2 and 3 of the $\beta$-globin gene as established by RNase mapping with RNA probes complementary to either the whole pAD pre-mRNA (Fig. 8B, lane 6) or to the AdML insert (lane 8). More importantly, separation of the two U17 RNAcoding regions by a functional exon resulted in accumulation of the accurately processed single-unit-length 
A
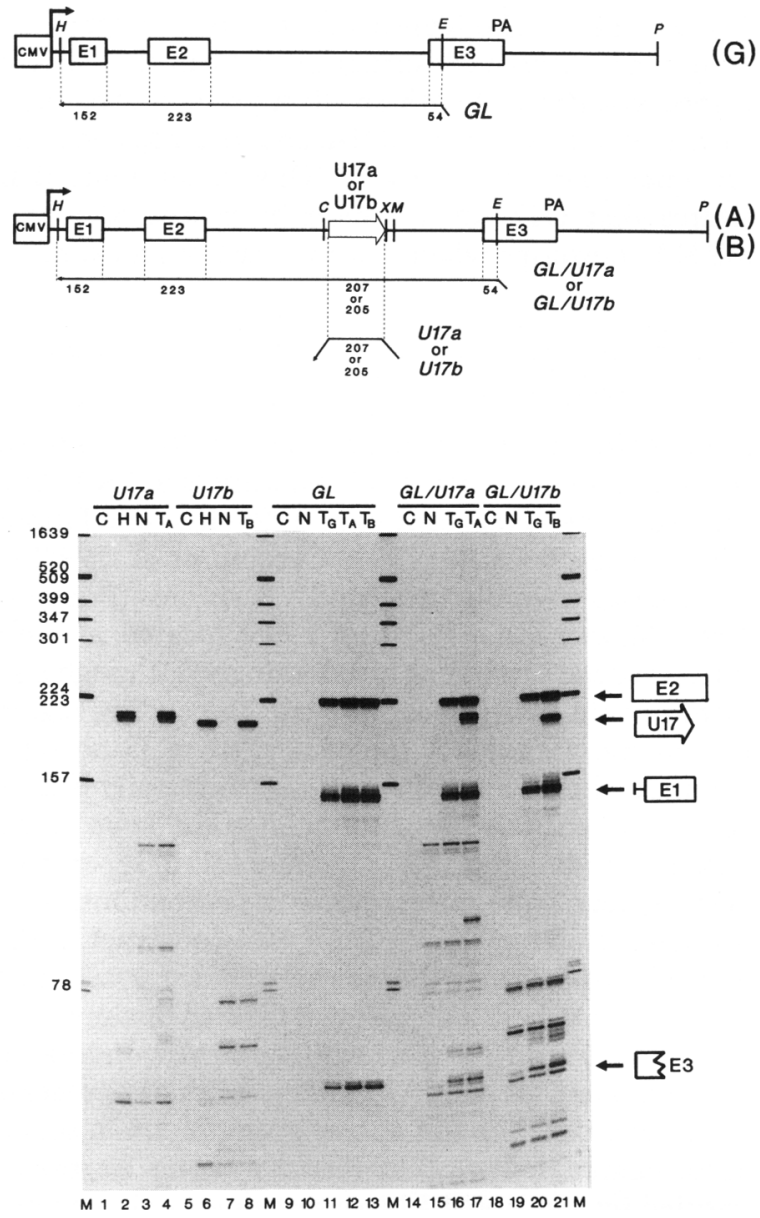

B
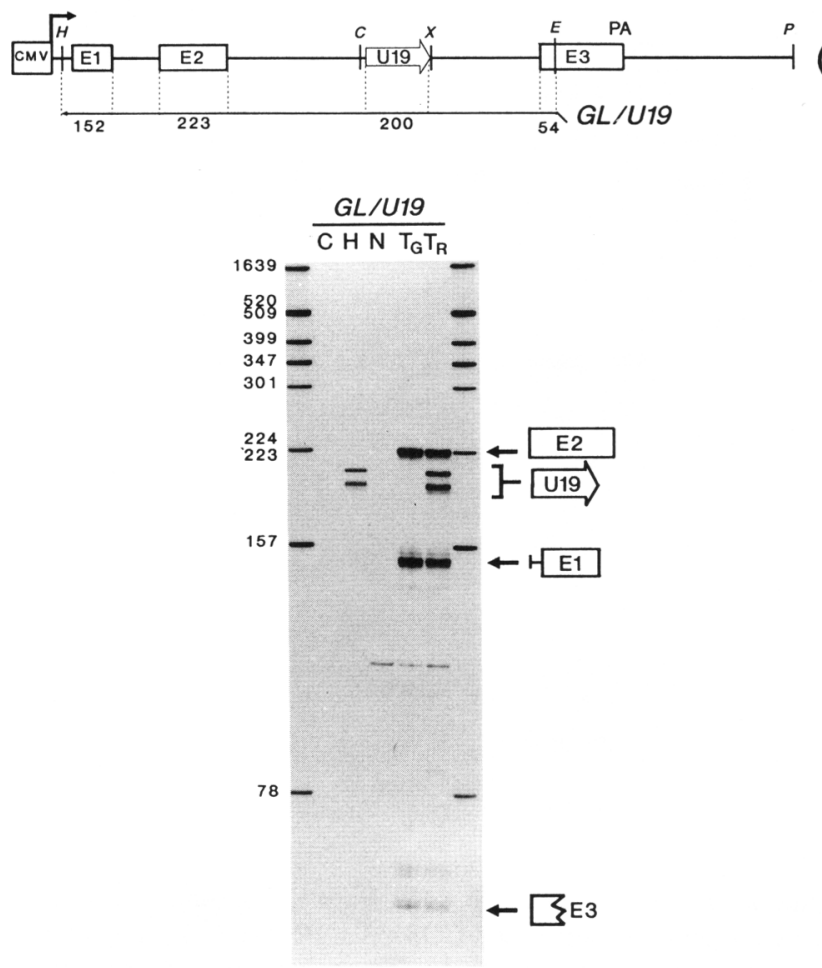

M $12345 \mathrm{M}$

Figure 6. Processing of snoRNAs from the intron 2 of the human $\beta$-globin pre-mRNA expressed in COS cells. RNase $A / T_{1}$ mapping of RNA isolated from cells transfected with expression constructs carrying U17a or U17b RNAs $|A|$, or U19 RNA $(B)$. Schemes of the expression constructs (called $\mathrm{G}, \mathrm{A}, \mathrm{B}$, and $\mathrm{R}$ ) are shown at the top of $A$ and $B$; important restriction sites (C, ClaI; E, EcoRI; H, HindIII; P, PstI; M, MluI; X, XhoI) and the polyadenylation site (PA) are indicated. Construct $G$ contains the human $\beta$-globin gene without snoRNA insertion. RNA probes and the expected lengths of the protected fragments are shown below the expression constructs. The probes and RNAs used for RNase mapping are indicated above the gel lanes. (Lanes C) E. coli tRNA; (lanes H) HeLa cell RNA $(0.5 \mu \mathrm{g}$ ); (lanes N) RNA (1.5 $\mu \mathrm{g}$ ) from mock-transfected COS cells; [lanes $T_{X}$ (where $x$ indicates the construct used for transfection)] RNA from transfected COS cells $(1.5 \mu \mathrm{g})$. Positions and structures of the protected fragments are indicated at right. Resolution of the U19-specific RNA into two protected bands is an artifact of RNase $A / T_{1}$ mapping; only one protected fragment is seen with other probes (T. Kiss and W. Filipowicz, in prep.). $(C)$ Subcellular localization of human U17a and U17b RNAs processed from the nonhost intron in trans-
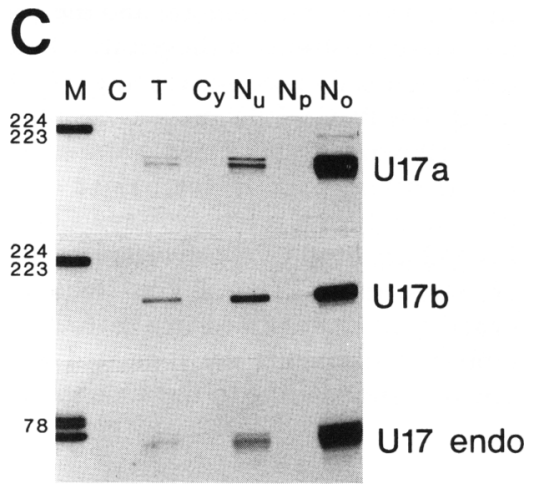
fected COS cells. RNA $(1 \mu \mathrm{g})$ isolated either from unfractionated cells $\langle T\rangle$ or from the cytoplasmic (Cy), nuclear ( Nu), nucleoplasmic ( $\mathrm{Np}$ ), or nucleolar (No) fractions of COS cells transfected with either $\mathrm{pA}$ (top row) or pB (middle row), were mapped with probes $U 17 a$ or $U 17 b$ (see $A$ ), respectively. Subcellular distribution of the endogenous simian $U 17$ RNA, revealed by mapping with the $U 17 b$ probe, is shown in the bottom row. (Lanes C) Control mappings with $E$. coli tRNA.

U17a and U17b RNAs (lane 6, cf. lane 2, control mapping of the human RNA). Insertion of the intronic sequence lacking a functional exon (construct $\mathrm{pC}$ ) into the $\mathrm{U} 17 \mathrm{a}$ / U17b spacer did not result in the formation of correctly processed U17 RNAs. However, the tandem U17a/U17b RNA also did not accumulate in COS cells (lane 4), suggesting that such artificial molecules containing a $>200$ - nucleotide-long spacer were not stable in vivo. Alternatively, spacer sequences might prevent accumulation of tandem molecules by interfering with proper folding of neighboring U17a and U17b RNA regions /see Discussion). Taken together, these observations corroborate further the notion that excised introns act as substrates for U17 snoRNA processing and that exonucleases are 

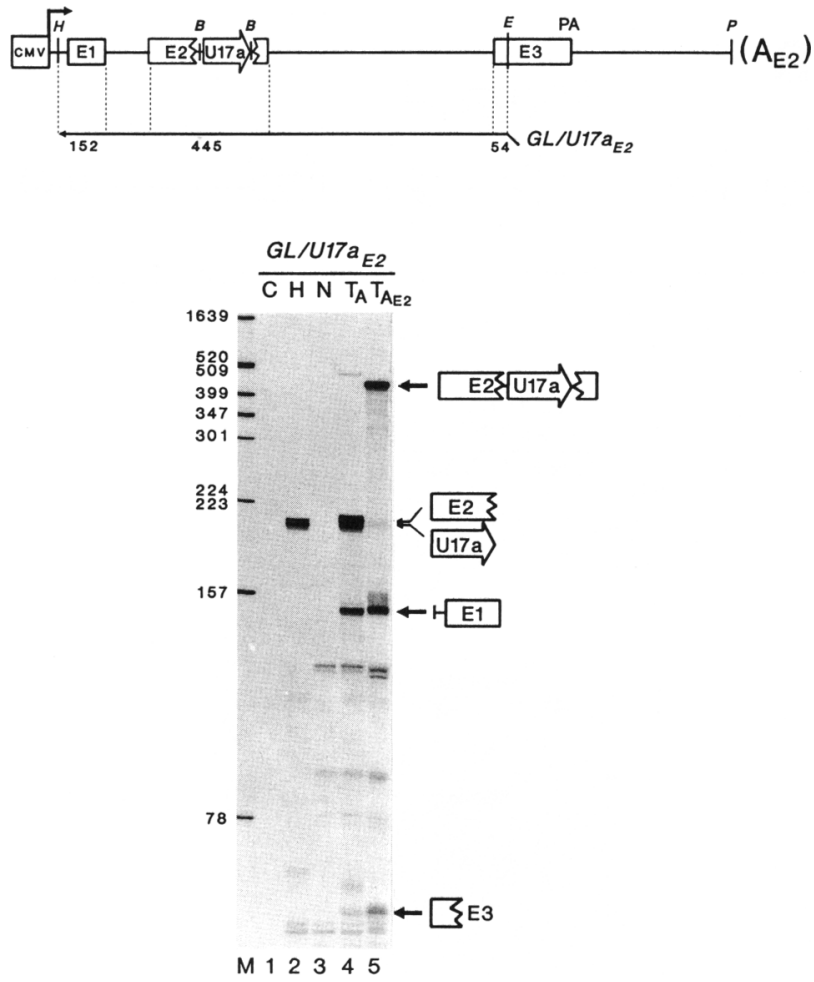

Figure 7. Processing in transfected COS cells of the chimeric pre-mRNA/snoRNA transcript containing U17a RNA sequence inserted into the second exon of the $\beta$-globin gene. The scheme of the construct $\mathrm{A}_{\mathrm{E} 2}$ used for transfections is shown at the top. The $G L / U 17 a_{\mathrm{E} 2}$ probe and lengths of the expected protected fragments are shown below. The following RNAs were used for mapping: (lane C) E. coli tRNA; (lane H) HeLa cell RNA; (lane N) RNA from non-transfected COS cells; (lanes $T_{A}$ and $T_{A E 2}$ ) RNA from COS cells transfected with $\mathrm{pA}$ and $\mathrm{pA}_{\mathrm{E} 2}$, respectively. Schematic structures of the protected fragments are indicated at right. (For other details, see the legend to Fig. 6.)

involved in generation of both the $5^{\prime}$ and $3^{\prime}$ termini of these RNAs.

\section{Discussion}

We have investigated the mechanism of biogenesis of three intron-encoded human snoRNAs: two variants of the U17 RNA, U17a and U17b, located in introns of the RCC1 gene, and the U19 RNA, which is encoded in the intron of an, as yet, not fully characterized gene. The results indicate that $5^{\prime} \rightarrow 3^{\prime}$ and $3^{\prime} \rightarrow 5^{\prime}$ exonucleases are involved in maturation of these snoRNAs and that excised and debranched introns are the most likely substrates of the processing reaction.

\section{Exonucleases are responsible for processing of $U 17$ and U19 snoRNAs in vitro and in vivo}

The results of experiments carried out with HeLa cell extracts provide the following evidence that exonu- cleases rather than endonucleases are involved in the processing of U17 and U19 RNAs from introns: (1) No endonuclease cutoff RNA fragments were detected among the processing products; $(2)$ blocking of the $5^{\prime}$ ends of substrate RNAs with $\mathrm{m}^{7} \mathrm{G}$ caps inhibited processing of the $5^{\prime}$ ends but not the $3^{\prime}$ ends; $(3)$ elimination of free $5^{\prime}$ and $3^{\prime}$ termini by circularization of substrate RNAs abolished processing of snoRNAs; (4) changing the flanking sequences of U17a RNA did not influence the accuracy of processing. It is important to emphasize that the effect of capping and circularization on the U17b RNA processing was studied with substrates encompassing the entire intron 2 of the RCC1 gene. Hence, if endonucleolytic cleavages in the pre-mRNA are responsible for generating free $5^{\prime}$ and $3^{\prime}$ termini acting as entry sites for exonucleases, such cleavages would have to occur outside of the intron sequence. However, as summarized below, no evidence of endonucleolytic cleavages within either intron or exon sequences was obtained in the in vivo experiments.

The conclusion that exonucleases are involved in the maturation of both termini of U17a, U17b, and U19 RNAs is corroborated by the results of experiments in which processing of the hybrid pre-mRNA/snoRNA transcripts was studied in transfected COS cells. All three snoRNAs were processed faithfully and efficiently when inserted into the intron 2 of the human $\beta$-globin gene even though it is not a natural host for snoRNAs. Because snoRNA-coding regions inserted into the globin intron were essentially devoid of flanking sequences originating from their host introns (see Materials and methods), it is unlikely that sequence-specific endonucleases are involved in the excision process. Other results of the in vivo experiments also speak against a role for endonucleases. (1) When U17 RNA sequence was inserted into an exon, snoRNA excision was abolished (Fig. 7). This result also argues against the possibility that endonucleases that recognize the snoRNA-coding region and cleave the pre-mRNA in a sequence-independent manner are involved in snoRNA processing. (2) Placement of two U17 RNA-coding regions separated by a 36-nucleotide-long spacer into a single intron of the $\beta$-globin gene resulted in accumulation of tandem U17 RNA molecules that are processed at outward but not inward U17 RNA ends, consistent with exonucleolytic degradation from free $5^{\prime}$ and $3^{\prime}$ ends of a debranched intron. Importantly, processing of the tandem U17 RNA into single-unit-length U17 RNAs could be rescued by insertion of a functional exon into the spacer separating the two snoRNA-coding regions (Fig. 8). (3) Finally, it should be noted that insertions of snoRNA-coding regions into the intron had no effect on levels of spliced $\beta$-globin mRNA accumulating in transfected COS cells (Fig. 6A). This finding argues against a possibility that processing of snoRNAs requires that pre-mRNA is cleaved endonucleolytically and suggests that single premRNA molecules yield both functional mRNA and processed snoRNA. Xenopus U17 RNA was also found to be processed exonucleolytically in microinjected oocytes (F. Amaldi, pers. comm.). 

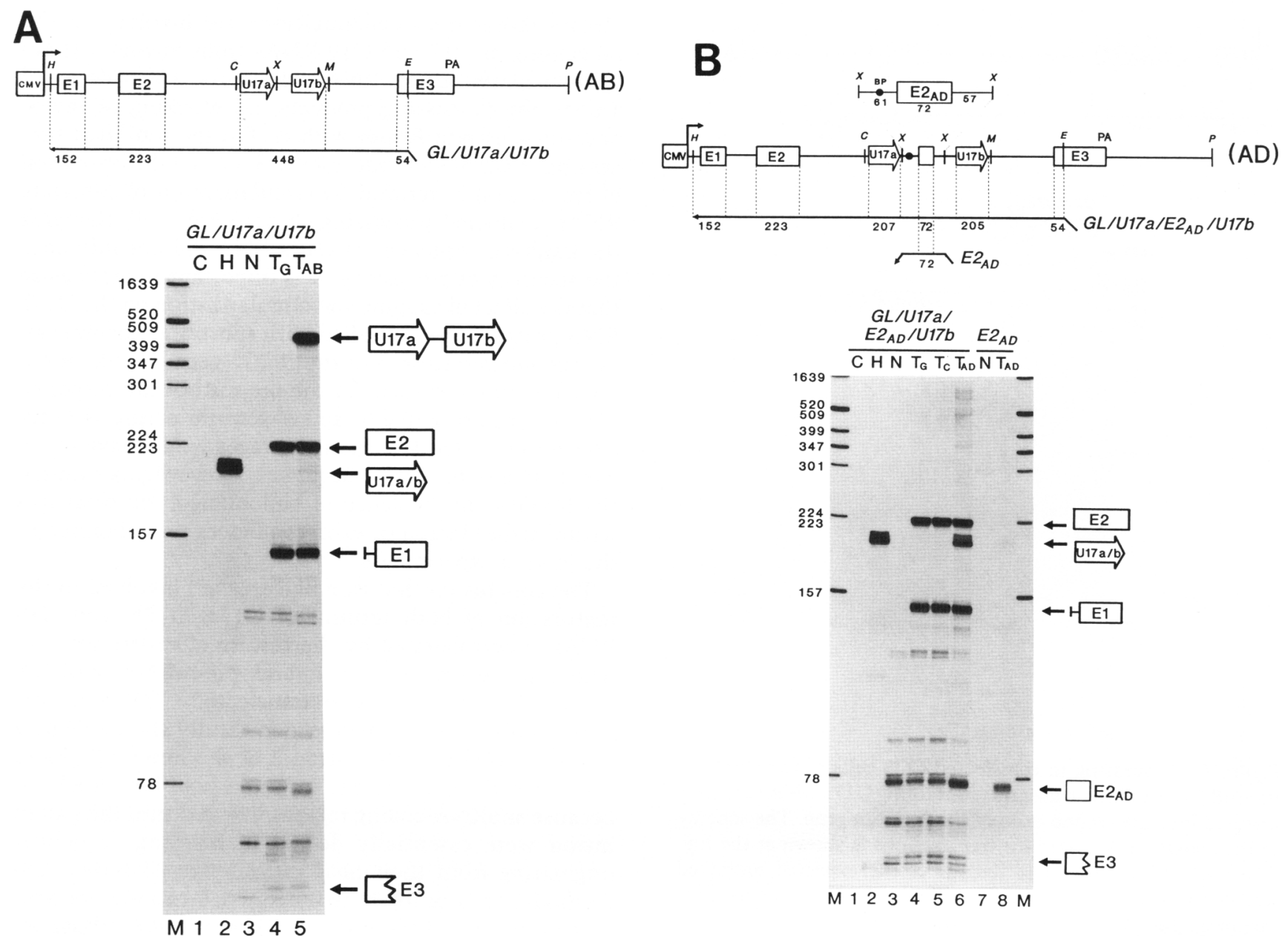

Figure 8. Processing of the chimeric pre-mRNA/snoRNA transcripts containing tandem U17a/Ul7b RNA-coding regions. $(A)$ Excision of the tandem U17a/U17b RNA from the second intron of the $\beta$-globin gene. The construct $A B$ used for transfection and the RNA probe used for mapping are shown at the top. $(B)$ Rescue of correct processing of U17 RNAs by insertion of the AdML exon into the spacer separating the U17a and U17b sequences. The expression construct AD and different probes used for RNase mapping are shown at the top. The position of the branch point (Konarska et al. 1985) upstream of the $3^{\prime}$ splice site of the AdML exon is indicated. Construct C, used as a control (lane 5), has a 190-nucleotide-long sequence derived from intron 2 of the RCC1 gene inserted between the U17a and U17b RNAs (see text; Materials and methods). The probes and RNA samples used for RNase mapping are indicated above the gel lanes. (Lanes C, H, N) RNA from E. coli, and from HeLa cells and nontransfected COS cells, respectively; (lanes $T_{\mathbf{x}}$ ) RNA from COS cells transfected with $1 \mu \mathrm{g}$ of recombinant plasmids indicated in the subscript. [For other details, see the legend to Fig. 6(A,B.)]

\section{A model for the processing of U17 and U19 snoRNAs}

On the basis of the results of this and previous work (Kiss and Filipowicz 1993), the following model can be proposed for the processing of U17 and U19 snoRNAs (Fig. 9). Pre-mRNA bearing the intron-encoded snoRNA undergoes splicing, resulting in the formation of mRNA and the release of an intron lariat. Debranching of the lariat produces a linear molecule that acts as a substrate for $5^{\prime} \rightarrow 3^{\prime}$ and $3^{\prime} \rightarrow 5^{\prime}$ exonucleases. Accumulation, in vitro, of products processed at the $5^{\prime}$ end but not at the $3^{\prime}$ end or vice versa (Figs. 1-3), indicates that $5^{\prime}$ and $3^{\prime}$ termini of snoRNAs can be processed independently of one another. As is also indicated by the in vitro results, maturation of the $3^{\prime}$ ends may occur in two steps. First, metastable intermediates with 5- to 9-nucleotide-long trailers are formed. Conversion of these products into snoRNAs with mature $3^{\prime}$ ends occurs slowly and is most probably catalyzed by an exonuclease (Kiss and Filipowicz 1993; this work, Figs. 1-3 and 9; for similar results obtained with U15 snoRNA, see Tycowski et al. 1993|. It is not known whether one or two different exonucleases participate in the maturation of $3^{\prime}$ ends. It is conceivable that only one nuclease is involved and processing becomes slow when the enzyme approaches the end of the snoRNA (see below).

Observations that U17 RNA is excised faithfully in vitro from an RNA precursor with altered flanking sequences and that U17 and U19 RNAs are processed accurately in vivo from the nonhost intron demonstrate 


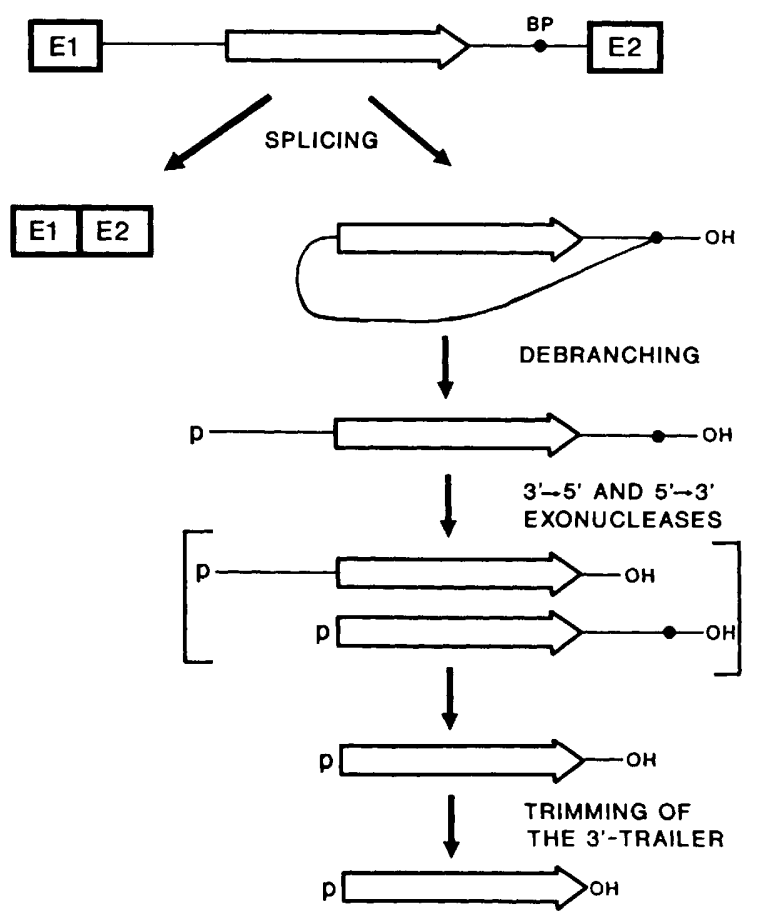

Figure 9. A model for processing of $\mathrm{U} 17$ and U19 snoRNAs. The $5^{\prime}$-phosphate and $3^{\prime}$-OH ends of an excised intron are indicated. The same termini have been identified in the in vitroprocessed snoRNAs (Kiss and Filipowicz 1993, and in prep.; Tycowski et al. 1993|. The snoRNA sequence may associate with snoRNP-specific proteins prior to the final processing steps. Final trimming at the $3^{\prime}$ terminus may also occur on RNAs with unprocessed $5^{\prime}$ ends. (For more details, see text.)

that coding sequences of snoRNAs contain all of the elements sufficient for correct processing. In the case of intron-encoded snoRNAs, which belong to the family of fibrillarin-associated RNAs, it is likely that the conserved stem-loop-stem structure encompassing the $C$ and D boxes and the RNA $5^{\prime}$ and $3^{\prime}$ termini (see introductory section) acts as an element important for snoRNA processing. Binding of fibrillarin and/or other proteins to these secondary structure elements could delineate the $5^{\prime}$ and $3^{\prime}$ ends of snoRNAs by protecting them from further trimming by processing exonucleases (Liu and Maxwell 1990; Tycowski et al. 1993; Balakin et al. 1994). Intronic snoRNAs that are not associated with fibrillarin, such as U17 or U19, do not possess the stemloop-stem structure with base-paired termini. Other, still unidentified, structural elements must be responsible for interactions with proteins and for processing of this class of snoRNAs.

\section{Pathways for processing of other intronic snoRNAs}

U17 and U19 snoRNAs studied in this work appear to follow a processing pathway different from that reported for two fibrillarin-associated intronic snoRNAs, U16 and U18. The latter RNAs were found to be excised from unspliced pre-mRNA transcripts by site-specific endonu- cleases, suggesting that snoRNA formation and splicing of the $L 1$ gene pre-mRNA, a host for U16 and U18 RNAs in Xenopus and humans, are mutually exclusive reactions. It has been suggested that suboptimal splice sites present in U16 containing introns may result in inefficient spliceosome assembly on these introns and that this may be one of the key elements responsible for the antagonistic processing (Fragapane et al. 1993; Prislei et al. 1993; Caffarelli et al. 1994).

We propose that the exonucleolytic processing mechanism may be a more common way to process intronencoded snoRNAs and that this pathway is probably not confined to the nonfibrillarin snoRNAs analyzed in this work. Contrary to U16 and U18 snoRNAs studied by Bozzoni and co-workers (Prislei et al. 1993; Caffarelli et al. 1994), no cutoff products reflecting endonuclease activities were detected during the processing of fibrillarinassociated snoRNAs U14 (Leverette et al. 1992), U15 (Tycowski et al. 1993), or U20 (T. Kiss and W. Filipowicz, unpubl.). Products generated during in vitro processing of the U15 RNA resemble products accumulating during maturation of snoRNAs studied in this work (Tycowski et al. 1993; see also introductory section). Likewise, capping or circularization of processing substrates prevents U15 RNA maturation, indicating that exonucleases are also involved in the formation of this snoRNA (K. Tycowski and J.A. Steitz, pers. comm.). In recent experiments it was found that mouse U14 is processed correctly from a nonparental human globin pre-mRNA intron in microinjected Xenopus oocytes (E.S. Maxwell, pers. comm.). Therefore, all of the available evidence suggests that the mechanism of processing of U14, U15, and U20 snoRNAs may be similar to that described for U17 and U19 RNAs. It will be interesting to find out whether exonucleases involved in maturation of snoRNAs are the same as those catalyzing degradation of standard introns.

\section{One intron/one snoRNA rule and mobility of snoRNA} genes during evolution

Certain features of the organization and evolution of nested mRNA/snoRNA genes can be explained more plausibly if an exonucleolytic pathway is a general mechanism for the maturation of snoRNAs. Despite the fact that single pre-mRNA transcripts can encode as many as five or six different sequence variants of one snoRNA or even of two snoRNA species, individual introns of pre-mRNA genes never carry more than one snoRNA-coding sequence (for review, see Filipowicz and Kiss 1993; Sollner-Webb 1993; Maxwell and Fournier 1995). This one intron/one snoRNA rule is best explained by exonucleolytic processing of introns being an obligatory step in maturation of snoRNAs. Accumulation of dimeric U17 RNA molecules processed from the globin intron containing two snoRNA-coding regions and rescue of correct processing into a single-unit snoRNAs by insertion of the exon into the spacer separating two U17 RNAs (Fig. 8) provide experimental support for this concept. 
Exonucleolytic processing of snoRNAs from excised introns and the apparent lack of specific processing signals in the regions that flank coding sequences of most snoRNAs may have facilitated the mobility of snoRNA genes between different introns or different transcription units during evolution. In different organisms, even among vertebrates, equivalent snoRNAs may be encoded in different genes or in different introns of the homologous gene (for review, see Maxwell and Fournier 1995). For example, in humans the two U17 RNA sequences are located in the RCC1 gene, whereas in Xenopus six U17 variants are present in introns of the S8 ribosomal protein gene (Kiss and Filipowicz 1993; Cecconi et al. 1994). In addition, in most vertebrates studied to date, U14 snoRNAs are encoded in the $h s c 70$ gene, but in Xenopus, additional U14 sequence variants are located in the gene for ribosomal protein S13 (Maxwell and Fournier 1995).

It has been suggested that cotranscription of snoRNAs with mRNAs encoding ribosomal or nucleolar proteins, or a mitotic regulator $\mathrm{RCCl}$, may be of importance in the regulation of ribosome biogenesis (for references, see introductory section). Although this may be true in certain cases, it has not been demonstrated yet. In view of the results presented in this work and the aforementioned mobility of intron-encoded snoRNAs, an alternative explanation of snoRNA gene localization may be more appropriate. Because most of the hosts for snoRNAs represent essential and actively transcribed constitutive genes, perhaps it is these features of the host genes that are most critical for expression of snoRNAs (for review, see Sollner-Webb 1993; Maxwell and Fournier 1995). Clearly, if snoRNA is processed from an excised intron by exonucleases, any actively transcribed and spliced pre-mRNA could act as its host.

\section{Materials and methods}

General procedures

Unless indicated otherwise, all techniques used for manipulating RNA, DNA, and oligodeoxynucleotides were performed according to standard procedures (Sambrook et al. 1989). The identity of all constructions was verified by sequence analysis. The following oligodeoxynucleotides were used in this study: (1) TGTAATACGACTCACTATAGGGTGAGTAAATCTGCTAAT; (2) CTTGGTACCTAAAAGAAAAGAAATAAT; (3) ATAGGATCCCTATCCAACGTGGATACACC; (4) ATAGGATCCTAAGGCTGTTTCCTGCATGG; (5) TCAGAATTCAACTGATACGTCTTCTAC $_{j}(6)$ CTGGGATCCTGATGGAGGTAGATGTC; (7) CTGCACGTGGATCCTGAG; (8) CATATCGATACATTACACTTTAACCC; $(9)$ GCTATCGATACTCGAGAACGCGTGTACACATATTGACCAA; (10) GGTGAATTCTTTGCCAAAG; (11) GTGATCGATTGTCCAACGTGGATA; (12) CCACTCGAGAAGGCTGTTTCCTGCA; (13) GTGATCGATTCCAACGTGGATACCC; (14) CCACTCGAGATATGTTTCCTGCATG; (15) GTGATCGATCATCCAGCGGTTGTC; (16) CCACTCGAGAAAAAAATTGTTTGCAC; (17) ACACTCGAGGTTACTCCAATTCCTCA; (18) TCCACGCGTATACTAGATATGTTTCC; (19) CCACTCGAGTAGTCCAGGGTTTCCTTG; (20) ATACTCGAGAAAAGGGATGCTGCGCC; (21) ATACTCGAGGCATTTAATCATTCTC; (22) GCGCTCGAGGCTTCCTACAGTTCACT; (23) ATTTGTTAAGGAT-
TCCAAGTAAC $_{i}(24)$ AAATGCGAAGTGCAGATCGTCTTC $;$ and (25) GATTCGCAGTGGTCGCTTCTTCTC.

\section{Plasmids for in vitro processing}

$\mathrm{pU} 17 \mathrm{a} / \mathrm{T} 7$, used as a template for synthesis of the U17a/T7 substrate, was described previously (Kiss and Filipowicz 1993). To obtain pU17b/T7, intron 2 of the $R C C 1$ gene was amplified by the polymerase chain reaction (PCR) with HeLa genomic DNA as a template and primers 1 and 2 . The $5^{\prime}$ primer (1) contains the T7 promoter sequence and 19 nucleotides of sequence complementary to the $5^{\prime}$ end of intron 2 of the $R C C 1$ gene. The $3^{\prime}$-end-specific primer (2) contains a 20 -nucleotidelong sequence complementary to the $3^{\prime}$ end of intron 2 and a $K p n I$ site at the end. The amplified fragment was cloned into the SmaI-KpnI sites of pUC19. The resulting construct, pU17b/T7, linearized with $K p n I$, was used as a template for in vitro transcription by T7 RNA polymerase. In addition to the full-length intron 2, the U17b/T7 RNA contains two 5'-terminal G residues. To obtain pU17a/PBS, the coding region of U17a RNA was PCR-amplified using pUl7a/T7 as a template and primers specific for the $5^{\prime}(3)$ and $3^{\prime}(4)$ end regions of U17a RNA, which introduce $B a m H I$ sites into the amplified products. The amplified fragment was cloned into the BamHI site of pBluescribe. The resulting pU17a/PBS was cleaved with EcoRI and transcribed by T3 RNA polymerase. To obtain pU19/T7, the fragment containing the coding region of U19 RNA and 74 and 107 bp of its upstream and downstream sequences was amplified with primers 5 and 6 and the HeLa cell DNA as a template. Cloning of the amplified fragment and in vitro synthesis of the U19/T7 substrate RNA were performed as described for the Ul7a/T7 substrate (Kiss and Filipowicz 1993).

In vitro processing of U17 and U19 RNAs

RNA processing substrates were synthesized in vitro with $\mathrm{T} 3$ or T7 RNA polymerase, $\left[\alpha^{32} \mathrm{P}\right] \mathrm{CTP}$ (sp. act. $30-40 \mathrm{Ci} / \mathrm{mmole}$ ) and recombinant plasmids linearized with appropriate restriction enzymes (see above; Goodall et al. 1990). Transcripts with the $5^{\prime}$-terminal $\mathrm{m}^{7} \mathrm{G}$ cap were synthesized in the presence of $1 \mathrm{~mm}$ $\mathrm{m}^{7} \mathrm{GpppG}$ cap analog (Pharmacia). All transcripts were gel purified before use. Circular RNA substrates were obtained as follows: $50-100 \mathrm{ng}$ of radiolabeled U17a/T7, U17b/T7, and U19/ T7 RNAs were treated with 0.1 unit of calf intestine phosphatase (CIP; Boehringer), phenol extracted, and incubated with the T4 polynucleotide kinase (Boehringer) in the presence of 0.1 mM ATP. The 5'-phosphorylated RNAs were gel purified and incubated with 20 units of the T4 RNA ligase (Boehringer) at $4^{\circ} \mathrm{C}$ for $48 \mathrm{hr}$ in $100 \mu \mathrm{l}$ reaction volume according to England et al. (1980). The covalently closed circular RNAs were separated from the linear forms on a denaturing $4 \%$ polyacrylamide gel.

The HeLa whole-cell S-100 extracts were prepared as described by Miller and Sollner-Webb (1981). Incubation conditions for the in vitro processing and analysis of the processing products have been described (Kiss and Filipowicz 1993).

\section{Construction of plasmids for transfection of COS-7 cells}

A HindIII- $P_{s t I}$ fragment containing the coding region of the human $\beta$-globin gene was isolated from pSP64-H $\beta \Delta 6$ (Krainer et al. 1984) and was cloned behind the CMV promoter of the mammalian expression vector pCB6 (Crosby et al. 1991), resulting in pG. The plasmid $\mathrm{pG}_{\mathrm{CXM}}$ is a derivative of $\mathrm{pG}$, in which a short sequence in the middle of the second intron of the globin gene between positions 943 and 954 (EMBL data base, entry V00499, numbering from the transcription start site of the 
globin gene) was replaced by a polylinker sequence (ATCGATACTCGAGAACGCGT) containing ClaI, XhoI, and MluI sites. This was achieved as follows. The $5^{\prime}$ half of the second intron of the globin gene was PCR-amplified with a $5^{\prime}$ primer (7) complementary to a region of exon 2 encompassing the BamHI site at position 477 and a $3^{\prime}$ primer $(8)$ complementary to a region in the middle (positions 927-943) of intron 2 and containing the ClaI site. The $3^{\prime}$ half of intron 2 was amplified with a $5^{\prime}$ primer (9) containing the ClaI, XhoI, and MluI sites and complementary to intron 2 positions $952-970$, and a $3^{\prime}$ primer (10) specific to the region around the EcoRI site (position 1394) in exon 3 of the gene. The two fragments were digested with ClaI, ligated together, digested with BamHI and EcoRI, and used to replace the $B a m H I-E c o R I$ fragment of $\mathrm{pG}$.

To obtain $\mathrm{pA}, \mathrm{pB}$, and $\mathrm{pR}$, the coding regions of $\mathrm{U17} \mathrm{a}, \mathrm{U17b}$, and U19 RNAs were PCR amplified with gene-specific primers (U17a, 11 and 12; U17b, 13 and 14; U19, 15 and 16); utilization of these primers results in inclusion of ClaI and XhoI sites adjacent, respectively, to the $5^{\prime}$ and $3^{\prime}$ ends of snoRNA-coding regions. To facilitate incorporation of these restriction sites, a few nucleotides representing authentic intron sequences had to be retained in the upstream and downstream flanks of U17a 12 upstream nucleotides/2 downstream nucleotides), U17b (5 upstream nucleotides/4 downstream nulceotides) and U19 (3 upstream nucleotides $/ 7$ downstream nucleotides) RNAs. Insertion of the U17a-, U17b-, and U19-specific PCR products into the ClaI and XhoI sites of $\mathrm{pG}_{\mathrm{CXM}}$ yielded $\mathrm{pA}, \mathrm{pB}$, and $\mathrm{pR}$, respectively. $\mathrm{pA}_{\mathrm{E} 2}$ was obtained by insertion of the coding region of U17a, excised from pU17a/pBS by BamHI, into the BamHI site of $\mathrm{pG}$ located in the second exon of the globin gene. To generate $\mathrm{pAB}$, a fragment of intron 2 of the $R C C 1$ gene, containing the coding region of U17b RNA flanked by 29 bp of upstream and $8 \mathrm{bp}$ of downstream sequences, was amplified with primers 17 and 18 and $\mathrm{pU} 17 \mathrm{~b} / \mathrm{T} 7$ as a template. The amplified fragment was cloned, by use of the PCR-introduced restriction sites, into XhoI and MluI sites of pA. To obtain pAD, the second exon of the AdML transcription unit, flanked by 61 bp of intron 1 and 57 bp of intron 2, was PCR-amplified with primers 19 and 20, which both carry the XhoI site. The amplified fragment was inserted into the $X$ hoI site of $\mathrm{pAB}$. A similar approach was used to create $\mathrm{pC}$, except that a fragment of intron 2 of the RCC1 gene (positions 2820-2990; EMBL data base, entry D00591) was amplified with primers 21 and 22 and inserted into the $X$ hoI site of $\mathrm{pAB}$. To generate $\mathrm{pE}$, the intron 2 of the $R C C 1$ gene flanked by 32 and 28 bp of upstream and downstream exonic sequences was PCR-amplified, with primers 23 and 24 , and cloned into the SmaI site of pBluescribe. The insert was then recovered by digestion with EcoRI and BamHI and cloned into the same sites of pCB6.

\section{Transfections, fractionation of cell extracts, and isolation of} RNA

Simian COS-7 cells (ATCC CRL 1651), were grown as monolayer cultures in Dulbecco's modified Eagle medium (GIBCO) supplemented with $10 \%$ fetal calf serum (GIBCO) and $2 \mathrm{~mm}$ glutamine. Typically, $10^{6} \mathrm{COS}$ cells, detached by standard trypsin/EDTA treatment, were transfected with $4 \mu \mathrm{g}$ (but see Fig. 8) of plasmid by use of DOTAP transfection-reagent (Boehringer/ and following the manufacturer's instructions. Cells were plated on $60-\mathrm{mm}$ petri dishes and incubated at $37^{\circ} \mathrm{C}$ in $5 \%$ $\mathrm{CO}_{2}$. Cells were collected $48 \mathrm{hr}$ after transfection. Subcellular fractionation of COS cells, pooled from 10 independent transfections, was carried out as described by Tyc and Steitz (1989). RNA from HeLa cells, from nontransfected and transfected COS cells, and from the nuclear, nucleoplasmic, cytoplasmic, and nucleolar fractions of COS cells was isolated by the guanidinium thiocyanate/phenol-chloroform method /Goodall et al. 1990).

\section{RNase $A / T_{1}$ mapping}

RNase $A / T_{1}$ mapping was done as described earlier (Goodall et al. 1990), except that RNA hybridization was carried out at $50^{\circ} \mathrm{C}$ rather than $45^{\circ} \mathrm{C}$. Complementary RNA probes were synthesized in vitro with T3 or T7 RNA polymerase, and conditions similar to those used for preparation of the processing substrates (see above). All probes were purified on $5 \%$ denaturing polyacrylamide gels.

To generate templates for preparation of probes $G L, G L /$ $U 17 a, G L / U 17 b, G L / U 19, G L / U 17 a_{E 2}, G L / U 17 a / U 17 b$, and $G L / U 17 a / E 2_{A D} / U 17 b$ the HindIII-EcoRI fragments of pG, pA, $\mathrm{pB}, \mathrm{pR}, \mathrm{pA} \mathrm{E}_{\mathrm{E} 2}, \mathrm{pAB}$, and $\mathrm{pAD}$, respectively, were subcloned into the HindIII-EcoRI sites of pBluescribe. Probes were synthesized by T7 RNA polymerase from HindIII-linearized templates. To generate probes $U 17 a$ and $U 17 b$, the ClaI-Xhol fragments of pA and $\mathrm{pB}$, containing the coding regions of $\mathrm{U17a}$ and $\mathrm{U} 17 \mathrm{~b}$ RNAs, respectively, were cloned into the $\mathrm{ClaI}-\mathrm{Xhol}$ sites of pBluescript II (Stratagene) and the SacI-linearized recombinant plasmids were transcribed by T3 RNA polymerase. The RCC1/IVS2 probe was synthesized by $T 7$ polymerase from a recombinant pBluescribe plasmid harboring the HindIII-PstI fragment of $\mathrm{pE}$.

\section{Acknowledgments}

We are grateful to Andrea Glaser for excellent technical assistance and Patrick Küry for many helpful suggestions on transient expression experiments. We also thank K. Tycowski and J.A. Steitz for sharing with us their unpublished results, and D. Heard, Y. Nagamine, G. Simpson, and K. Tycowski for critical reading of the manuscript.

The publication costs of this article were defrayed in part by payment of page charges. This article must therefore be hereby marked "advertisement" in accordance with 18 USC section 1734 solely to indicate this fact.

\section{References}

Balakin, A.G., R.A. Lempicki, G.M. Huang, M.J. Fournier. 1994. Saccharomyces cerevisiae U14 small nuclear RNA has little secondary structure and appears to be produced by post-transcriptional processing. J. Biol. Chem. 269: 739-746.

Beltrame, M. and D. Tollervey. 1992. Identification and functional analysis of two U3 binding sites on yeast pre-ribosomal RNA. EMBO J. 11: 1531-1542.

Caffarelli, E., M. Arese, B. Santoro, P. Fragapane, and I. Bozzoni. 1994. In vitro study of processing of the intron-encoded U16 snoRNA in X. laevis. Mol. Cell. Biol. 14: 2966-2974.

Cecconi, F., P. Mariottini, F. Loreni, P. Pierandrei-Amaldi, N. Campioni, and F. Amaldi. 1994. U17 ${ }^{\mathrm{Xs8}}$, a small nucleolar RNA with a 12 nt complementarity to 18 S rRA and coded by a sequence repeated in the six introns of Xenopus laevis ribosomal protein S8 gene. Nucleic Acids Res. 22: 732-741.

Chu, S., R.H. Archer, J.M. Zengel, and L. Lindahl. 1994. The RNA of RNase MRP is required for normal processing of ribosomal RNA. Proc. Natl. Acad. Sci. 91: 659-663.

Crosby, S.D., J.J. Puetz, K.S. Simburger, T.J. Fahmer, and J. Milbrandt. 1991. The early response gene NGFI-C encodes a zinc finger transcriptional activator and is a member of the GCGGGGGCG (GSG) element-binding protein family. Mol. Cell. Biol. 11: 3835-3841. 
England, T.E., A.G. Bruce, and O.C. Uhlenbeck. 1980. Specific labeling of $3^{\prime}$ termini of RNA with T4 RNA ligase. Methods Enzymol. 65: 65-74.

Filipowicz, W. and T. Kiss. 1993. Structure and function of small nucleolar snRNPs. Mol. Biol. Rep. 18: 149-156.

Fournier, M.J. and E.S. Maxwell. 1993. The nucleolar snRNAs: Catching up with the spliceosomal snRNAs. Trends Biochem. Sci. 18: 131-135.

Fragapane, P., S. Prislei, A. Michienzi, E. Caffarelli, and I. Bozzoni. 1993. A novel small nucleolar RNA (U16) is encoded inside a ribosomal protein intron and originates by processing of the pre-mRNA. EMBO I. 12: 2921-2928.

Goodall, G.J., K. Wiebauer, W. Filipowicz. 1990. Analysis of pre-mRNA processing in transfected plant protoplasts. Methods Enzymol. 181: 148-161.

Hashimoto, C. and J.A. Steitz. 1983. Sequential association of nucleolar 7-2 RNA with two different autoantigenes. $/$. Biol. Chem. 258: 1379-1382.

Hernandez, N. 1992. Transcription of vertebrate snRNA genes and related genes. In Transcriptional regulation (ed. S.L. McKnight and K.R. Yamamotol, pp. 281-313. Cold Spring Harbor Laboratory Press, Cold Spring Harbor, New York.

Hughes, J.M.X. and M. Ares Jr. 1991. Depletion of U3 small nucleolar RNA inhibits cleavage in the $5^{\prime}$ external transcribed spacer of yeast pre-ribosomal RNA and prevents formation of 18S ribosomal RNA. EMBO J. 10: 4231-4239.

Kass, S., K. Tyc, J.A. Steitz, and B. Sollner-Webb. 1990. The U3 small nucleoar ribonucleoprotein functions in the first step of preribosomal RNA processing. Cell 60: 897-908.

Kiss, T. and W. Filipowicz. 1993. Small nucleolar RNAs encoded by introns of the human cell cycle regulatory gene RCC1. EMBO I. 12: 2913-2920.

Konarska, M.M., P.J. Grabowski, R.A. Padgett, and P.A. Sharp. 1985. Characterization of the branch site in lariat RNAs produced by splicing of mRNA precursors. Nature 313: 552557.

Krainer, A.R., T. Maniatis, B. Ruskin, and M.R. Green. 1984. Normal and mutant human $\beta$-globin pre-mRNAs are faithfully and efficiently spliced in vivo. Cell 36:993-1005.

Leverette, R.D., M.T. Andrews, and E.S. Maxwell. 1992. Mouse U14 snRNA is a processed intron of the cognate $h s c 70$ heat shock pre-messenger RNA. Cell 71: 1215-1221.

Li, H.V., J. Zagorski, and M.J. Foumier. 1990. Depletion of U14 small nuclear RNA (snR128) disrupts production of $18 \mathrm{~S}$ rRNA in Saccharomyces cerevisiae. Mol. Cell. Biol. 10: 1145-1152.

Liu, J. and E.S. Maxwell. 1990. Mouse U14 snRNA is encoded in an intron of mouse cognate $h s c 70$ heat shock gene. Nucleic Acids Res. 18: 6565-6571.

Lygerou, Z., P. Mitchell, E. Petfalski, B. Séraphin, and D. Tollervey. 1994. The POP1 gene encodes a protein component common to the RNase MRP and RNase P ribonucleoproteins. Genes \& Dev. 8: 1423-1433.

Maxwell, E.S. and M.J. Fournier. 1995. The small nucleolar snRNAs. Annu. Rev. Biochem. (in press).

Miller, K.G. and B. Sollner-Webb. 1981. Transcription of mouse rRNA genes by RNA polymerase I: in vitro and in vivo initiation and processing sites. Cell 27: 165-174.

Morrissey, J.P. and D. Tollervey. 1993. Yeast snR30 is a small nucleolar RNA required for $18 \mathrm{~S}$ rRNA synthesis. Mol. Cell. Biol. 13: 2469-2477.

Muhlrad, D., C.J. Decker, and R. Parker. 1994. Deadenylation of the unstable mRNA encoded by the yeast MFA2 gene leads to decapping followed by $5^{\prime} \rightarrow 3^{\prime}$ digestion of the transcript. Genes \& Dev. 8: 855-866.

Murthy, K.G.K., P. Park, and J.L. Manley. 1991. A nuclear mi- crococcal-sensitive ATP-dependent exoribonuclease degrades uncapped but not capped RNA substrates. Nucleic Acids Res. 19: 2685-2692.

Nag, M.K., T.T. Thai, E.A. Ruff, N. Selvamungan, M. Kunnimalaiyaan, and G.L. Elicieri. 1993. Genes for E1, E2, and E3 small nucleolar RNAs. Proc. Natl. Acad. Sci. 90: 9001-9005.

Nicoloso, M., M. Caizergues-Ferrer, B. Michot, M.-C. Azum, and J.-P. Bachellerie. 1994. U20, a novel small nucleolar RNA, is encoded in an intron of the nucleolin gene in mammals. Mol. Cell. Biol. 14: 5766-5776.

Peculis, B.A. and J.A. Steitz. 1993. Disruption of U8 nucleolar snRNA inhibits $5.8 \mathrm{~S}$ and $28 \mathrm{~S}$ rRNA processing in the Xenopus oocyte. Cell 73: 1233-1245.

Prislei, S., A. Michienzi, C. Presutti, P. Fragapane, and I. Bozzoni. 1993. Two different snoRNAs are encoded in introns of amphibian and human $\mathrm{L} 1$ ribosomal protein genes. Nucleic Acids Res. 21: 5824-5830.

Qu, L.-H., M. Nicoloso, B. Michot, M.-C. Azum, M. CaizerguesFerrer, M.-H. Renalier, and J.-P. Bachellerie. 1994. U21, a novel small nucleolar RNA with a 13 nt. complementarity to $28 \mathrm{~S}$ rRNA, is encoded in an intron of ribosomal protein L5 gene in chicken and mammals. Nucleic Acids Res. 22: 4073-4081.

Reddy, R., E.M. Tan, D. Henning, K. Nohga, and H. Busch. 1983. Detection of a nucleolar 7-2 ribonucleoprotein and a cytoplasmic 8-2 ribonucleoprotein with autoantibodies from patients with scleroderma. J. Biol. Chem. 258: 1383-1386.

Ruff, E.A., O.J. Rimoldi, B. Raghu, and G.L. Eliceiri. 1993. Three small nucleolar RNAs of unique nucleotide sequences. Proc. Natl. Acad. Sci. 90: 635-638.

Sambrook, J., E.F. Fritsch, and T. Maniatis. 1989. Molecular cloning: A laboratory manual. Cold Spring Harbor Laboratory Press, Cold Spring Harbor, New York.

Savino, R. and S.A. Gerbi. 1990. In vivo disruption of Xenopus U3 snRNA affects ribosomal RNA processing. EMBO $I$. 9: 2299-2308.

Schmitt, M.E. and D.A. Clayton. 1993. Nuclear RNase MRP is required for correct processing of pre-5.8S rRNA in Saccharomyces cerevisiae. Mol. Cell. Biol. 13: 7935-7941.

Sollner-Webb, B. 1993. Novel intron-encoded small nucleolar RNAs. Cell 75: 403-405.

Sollner-Webb, B., K. Tyc, and J.A. Steitz. 1995. Ribosomal RNA processing in eukaryotes. In Ribosomal RNA: Structure, evolution, gene expression and function in protein synthesis (ed. R.A. Zimmermann and A.E. Dahlbergl, CRC Press, Boca Raton, FL. (in press).

Tollervey, D. 1987. A yeast small nuclear RNA is required for normal processing of pre-ribosomal RNA. EMBO I. 6: 41694175.

Tyc, K. and J.A. Steitz. 1989. U3, U8, and U13 comprise a new class of mammalian snRNPs localized in the cell nucleolus. EMBO I. 8: 3113-3119.

Tycowski, K.T., M.-D. Shu, and J.A. Steitz. 1993. A small nucleolar RNA is processed from an intron of the human gene encoding ribosomal protein S3. Genes \& Dev. 6: 1120-1130. . 1994. Requirement for intron-encoded U22 small nucleolar RNA in $18 \mathrm{~S}$ ribosomal RNA maturation. Science 266: 1558-1561. 


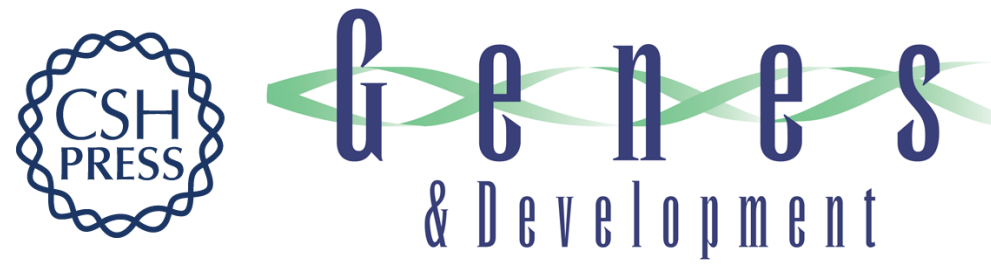

\section{Exonucleolytic processing of small nucleolar RNAs from pre-mRNA introns.}

T Kiss and W Filipowicz

Genes Dev. 1995, 9:

Access the most recent version at doi:10.1101/gad.9.11.1411

References This article cites 39 articles, 15 of which can be accessed free at:

http://genesdev.cshlp.org/content/9/11/1411.full.html\#ref-list-1

License

Email Alerting

Service

Receive free email alerts when new articles cite this article - sign up in the box at the top right corner of the article or click here.

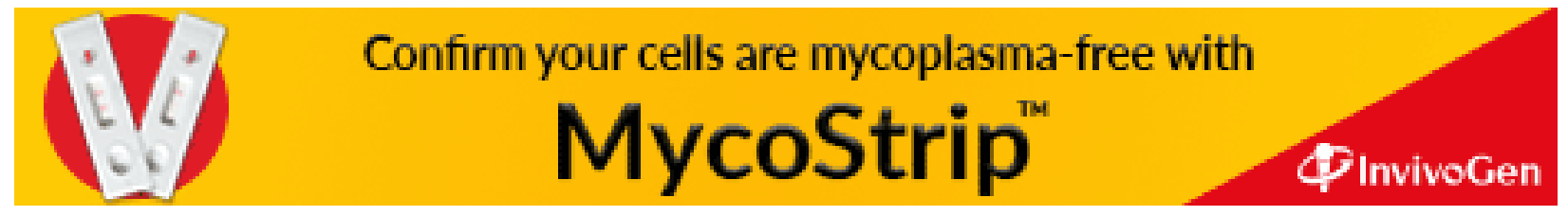

